\title{
EMPIRE, SOVEREIGNTY, AND JUSTICE IN FRANCISCO DE VITORIA'S INTERNATIONAL THOUGHT: A RE-INTERPRETATION OF DE INDIS (1532)
}

\author{
IMPERIO, SOBERANÍA YJUSTICIA EN EL PENSAMIENTO \\ INTERNACIONALISTA DE FRANCISCO DE VITORIA: \\ UNA RE-INTERPRETACIÓN DE DE INDIS (1532)
}

\section{Luis ValenZuela-Vermehren*}

\begin{abstract}
This article attempts to offer an alternative interpretation of Francisco de Vitoria's international thought. Much of the literature on his De Indis (1532) characterizes his view of international order as one that either opposed of justified Spanish imperialism in the New World. As against such conventional interpretations, I argue that this text is not fundamentally about the condemnation or justification of empire but, more importantly, a broad view of order that limits the exercise of state power and the recourse to war. Furthermore, it constructs a clear notion of sovereignty and international relations applicable to political communities based on an iusnaturalistic conceptualization of law and politics in the Spanish Renaissance.
\end{abstract}

Key words: Francisco de Vitoria, International Relations, Sovereignty, Justice, International Law.

RESUMEN: Este artículo ofrece una interpretación alternativa del pensamiento internacionalista de Francisco de Vitoria. Un segmento importante de la literatura en torno a De Indis (1532) caracteriza su visión del orden internacional como aquel que pudo ya sea oponerse o bien justificar el imperialismo español en el Nuevo Mundo. A diferencia de tales interpretaciones, se argumenta que dicho tracto no constituye, en lo fundamental, una condena, así como tampoco una justificación, del impulso imperial, sino una amplia visión del orden internacional que limita la conducta del poder estatal y el recurso a la guerra. Además, Vitoria ofrece una clara noción de soberanía y de las relaciones internacionales entre comunidades políticas fundamentada en una conceptualización iusnaturalista del derecho y de la política durante el renacimiento español.

Palabras clave: Francisco de Vitoria, Relaciones Internacionales, Soberanía, Justicia, Derecho Internacional.

Returning to the historical and intellectual roots of legal and political thought almost always offers a unique opportunity for understanding the present or for re-examining on-going debates in ethics and international affairs. Much of what we recognize as public international law, including human rights conventions and the laws of war owe much of their current vitality to the intellectual efforts of the so-called Spanish theologian-jurists

\footnotetext{
Profesor Asistente, Departamento de Sociología y Ciencia Política, Universidad Católica de Temuco. PhD International Relations, The London School of Economics \& Political Science; Magister en Ciencia Política, PUC, BA Political Science, University of California at Berkele, correo electrónico: lvalenzuela@uct.cl.
} 
of the sixteenth century. While their work has undergone some degree of examination in the current literature, there is no systematic treatment of their thought on international order. The Dutch jurist, Hugo Grotius (1583-1645), is conventionally cast as the founder of the modern law of nations, but it is equally the case that the work of the Spanish, to which Grotius himself referred, exerted influence on the later development of law and even constructed, one hundred years before Hobbes, a contractual theory of the state ${ }^{1}$. It seems both appropriate and profitable, then, to explore the thought of the Dominican theologian, Francisco de Vitoria (1483-1546) who initiated an intellectual venture that took theology from its medieval speculative activities to the problems of politics and law associated with increasing inter-state competition, reason of state, and the unfolding of European empire $^{2}$.

An examination of some of the early modern principles of justice set forth by the Spanish thinkers during the European Renaissance allows us to locate the first arguments centering on the rightful and licit use of the power associated with the emerging territorial state. Indeed, as against the Italian conception of ragione di stato, implicit in Machiavelli's thoughts on statecraft and explicitly set forth in the works of writers such as Francesco Guicciardini (1483-1540), the intellectual output of the so-called Escuela de Salamanca, whose figurehead was Vitoria, initiated a kind of rearguard action against the separation of ethics from politics and drew upon Thomistic natural law for the determination of standards of state conduct both within and between states.

I argue that Vitoria's view of order and law were attempts at answering ethical questions associated with the politics of the emerging state and are as current and vital now as they were was five hundred years ago. That his and his colleagues' intellectual pursuits provided an ethical and philosophical underpinning to the development of actual law, as Nys put it, is a sign of their relevance to questions that characterize contemporary debates ${ }^{3}$. The point is that a return to the first sources on these issues may help to clarify current debates and, perhaps, enrich them by furnishing historical perspective and conceptual and theoretical depth.

In what follows I will outline Vitoria's view of international order. I will then explore how De Indis deployed a notion of sovereignty beyond Europe, explored the role of power and the limits to which he believed it was subject, and his view of the role of justice in the establishment of order among sovereign communities.

\section{FRANCISCO DE VITORIA AND DE INDIS}

A standard approach to studying Vitoria's De Indis has involved a detailed and lengthy analysis of each of the articles (or 'titles') within the text. An overt purpose of this particular procedure has been to determine whether Vitoria was an enthusiast or opponent

\footnotetext{
1 For a discussion of this latter question, see, for example, Naszalyi (1948); Recaséns Siches (1931); SánChez Agesta (1959).

2 For an account of theological reform in sixteenth century Spain, see Belda Plans (2000). For an overview of Spanish political thought, see Hamilton (1963); NoreÑa (1975), White ed. (1997)

3 Nys ed. (1917).
} 
of ruthless empire. This conventional reading of the text is substantially misleading because it assumes that De Indis can be read with only these questions in mind, and that the conclusions of condemnation or praise of Spanish empire are the only ones at which we may fruitfully arrive. However, the apparent subject matter of De Indis, the questions surrounding the Spanish presence in the Indies and the treatment of the Indians, is but the "plot" behind which lies the more profound content of his relectio: the individual rights inherent in the nature of man and in the political community, and the legitimate or just means by which different communities may come into contact with one another.

To this effect, I argue that there are three substantive arguments underpinning De Indis each of which correspond to three segments of the text itself: 1) the idea of the sovereignty and legitimacy of non-European or non-Christian states, and their status as equals by nature whose sovereignty is to be acknowledged; 2) the notion that there are ethical limits to be placed on the use of force and on the recourse to war, as well as a denial of empire as a legitimate form of governance or communication between communities; and 3) the question of the order of justice, and principles that may be deduced from it, as the order that properly regulates relations between all communities. In this respect, I am expounding Vitoria's doctrine of international relations in a manner not expressed in any of the current literature. Such an exposition, furthermore, is at variance with others that have seen Vitoria as an apologist of empire. The argument offered here also denies the assertion that Vitoria had developed no notion of sovereignty; that he had no conception of who the members of international society were; and that he did not believe that relations between Christians and non-Christians could be articulated on a common basis. These, I argue, are the salient themes emerging from a close reading of Vitoria's lecture on the Indies, which are linked, both in De Indis and other lectures, to state power, how it should be used, and for what purposes.

\section{THE VITORIAN IMAGE OF THE GLOBE}

\subsection{Communitas Orbis Or Totus Orbis}

In De potestate civili (On Civil Power, 1528) ${ }^{4}$ Vitoria outlines a theory of the state predicated on an Aristotelian and Thomistic conception of the origin and nature of power and community. Two corollaries follow from his discussion. First, as with that political power or the power of government is at the service of the community. Its role indeed is one of impelling the social order toward the common good. The common good itself is largely a function of an order of justice within society and of a set of faculties that allow government to exercise both internal sovereignty and sovereign independence. Second, unlike theories upholding the Divine Right of Kings, government power, though in a position of pre-eminence over the community, is entirely and unequivocally subject to the laws enacted by it since power itself is said to belong to and is, indeed, a constitutive part of the community. Unlike Hobbes' Leviathan, the institutionalization of power does not involve a surrendering of rights to the sovereign but rather a transfer of authority that

4 See the standard translation in Pagden and Lawrence (1991). 
does not furnish power with exceptional or discretional faculties. A keynote feature, then, of such a social order is the maintenance of fundamental and natural rights among social agents and the limitations placed by natural right (or justice) on the exercise of government power, as well as a natural right to sovereign independence.

This image of the state re-emerges as an analogy to describe the framework within which inter-state relations could legitimately be conducted. Thus, De potestate civili draws up not merely a conception of the state but also, implicitly, a conception of the world simultaneously. "The whole world (totus orbis), which is in a sense a commonwealth," Vitoria maintained, "has the power to enact laws which are just and convenient to all men; and these make up the law of nations" 5 . The idea of the "whole world" is not a cursory statement but, more importantly, an organic conception of the totality of the globe, of the unity of mankind, or as one Spanish scholar has noted, the assertion of a universal community of humanity governed, as Gierke held, by "One-Spirit" and "OneOrdinance" 6 . This idea can be found in medieval political thought which begins with the notion of a whole that attaches to every part "down to and including the Individual" intrinsic value ${ }^{7}$. As in the Vitorian conception of the state, which conceives of the individual and the sovereign community as mirroring one another in aims and purposes, so too do these parts, as particular wholes, mirror a greater whole or substantive unity embodied in humankind and directed by the divine ordering principles of the universe. Gierke understood this in the following fashion:

[...] every Being, in so far as it is a Whole, is a diminished copy of the World; it is a Microcosmus or Minor Mundus in which the Macrocosmus is mirrored. In the fullest measure this is true of every human individual; but it holds good also of every human community and of human society in general. Thus the Theory of Human Society must accept the divinely created organization of the Universe as a prototype of the first principles which govern the construction of human communities ${ }^{8}$.

We thus bear witness here to the philosophical and teleological view of a universal order as envisioned by Aristotelian philosophy, and further developed by Christian political doctrine. This worldview comprises three overlapping spheres: the individual, human society, and humankind. Similarly, it is this essentially medieval outlook that informs Vitoria's conception of international community. However, unlike the medieval theocratic conception of the world, Vitoria did not partake of the notion of an Orbus Christianus, a world brought into political and religious unity by a Universal Monarchy with emperor and pope as its highest authorities. And one key objective of De Indis was that of destroying that early idea of Christian politico-religious universalism in favor of a naturalistic worldview predicated upon the doctrine of natural right. In sum, this meant,

\footnotetext{
5 Pagden and Lawrence (1991) p. 40.

6 Truyol y Serra (1947) p. 126. Gierke (1968) p. 8.

7 Gierke (1968) p. 7.

8 Gierke (1968) p. 8.
} 
as I shall demonstrate below: 1) "constructing" sovereignty outside the Christian world; 2) limiting in this manner the exercise of imperial (and ecclesiastical) power; and 3) envisioning a set of just principles governing an emerging inter-state order.

\section{DE INDIS AND THE CONSTRUCTION OF SOVEREIGNTY BEYOND CHRISTIAN EUROPE}

One of Vitoria's chief tasks in the first part of this relectio was that of bolstering the notion that indigenous communities, in fact, possessed dominion or sovereign status. At the heart of this question lay the fundamental consideration of the status of the Indians as rational beings. Dominion in man, and the rights thereby attaching to him, are predicated upon a characterization of man as possessing reason and consequently moral agency and dignity. In Spain, it was Juan Ginés de Sepúlveda's Democrates Alter (c.1544) that famously supported the Aristotelian view of natural slavery and established that war and rule over such natural slaves were justifiable. The idea was based on the assumption that certain men are naturally wiser than others who, on the other hand, are more aptly endowed with capacities generally associated with household or servile tasks. Aristotle himself had thus argued:

We may thus conclude that all men who differ from others as much as the body differs from the soul, or an animal from a man (and this is the case with all whose function is bodily service, and who produce their best when they supply such service), all such are, by nature slaves, and it is better for them [...] to be ruled by a master. (Politics, $\left.1254^{\mathrm{b}} \$ 8\right)^{9}$.

From this general conception it was possible for Sepúlveda to conclude:

Philosophers see slavery as inferior intelligence along with inhuman and barbarous customs [...] Those who surpass the rest in prudence and talent, although not in physical strength, are by nature the masters. Those, on the other hand, who are retarded or slow to understand, although they may have the physical strength necessary for the fulfillment of all their necessary obligations, are by nature slaves, and it is proper and useful that they be so, for we even see it sanctioned in divine law itself, because it is written in the Book of Proverbs that he who is a fool shall serve the wise.... If they reject such rule, then it can be imposed upon them by means of arms, and such a war will be just according to the laws of nature ${ }^{10}$.

While this view found acceptance in the Spanish court, the School of Salamanca, notes one scholar, condemned its implicit "natural aristocratism" and was quick to

\footnotetext{
9 Aristotle (1946) p. 13.
}

10 Sepúlveda (2012). 
condemn the printing of such an "unsound doctrine"11. Vitoria disparages this particular line of reasoning and additionally criticizes other religious grounds (or "unjust titles") such as sin, lack of Christian faith and infidelity as sufficient justifications for warring upon the Indies and depriving the inhabitants of self-rule and property.

The general strategy of Vitoria's argument thus involved extolling to a significant degree the rational character of the newly found communities. This also entailed denying religious imperatives or Christian doctrine as legitimate motivations for depriving the Indians of self-rule and property ownership (of dominium in its broadest definition). Dominion, in the Thomistic view, is a faculty or right arising from the nature of rational man himself.

\subsection{Natural Slaves?}

The manner in which Vitoria discussed the question of dominion in the Indies entailed a reference to the idea that irrational creatures (animals) do not in fact possess dominion but rather are "moved", unlike men, by something other than the faculty of reason. A corollary of this is that irrational creatures, furthermore, are at the service of those possessing rational faculties. Vitoria follows Aquinas in the assertion that "by this argument brutes, which do not move by their own will but are moved by some other, as Aquinas says (ST I-II, 1-2) cannot have any dominion"12. The question examined here by Vitoria is preceded by a query, quite evidently alluding to natural slavery arguments, regarding whether "men who are irrational or mad can be true masters" (domini) ${ }^{13}$. The exemplification utilized by Vitoria, (the use of the distinction between rational and irrational creatures) served as a means of attaching (subjective) rights and dominion to the Christian concept of man, and for implicitly disassociating the indigenous communities of the New World from a categorization belonging exclusively to non-rational species or to an "inferior" order of semi-rational men. Irrational creatures certainly could not possess dominion, for "dominion is a legal right (dominium est ius)"14. In this very sense, it is inappropriate to speak of animals as possessing rights because as irrational creatures they cannot, unlike men, suffer injustice nor engage in the task, by way of free will, of making moral choices. Justice

11 GonZález (1984) p. 211.

12 Pagden and Lawrence (1991) p. 248. Indeed, Aquinas argues (ST, I-II, 1-2): “[...] those things that are possessed of reason, move themselves to an end; because they have dominion over their actions through their free-will, which is the "faculty of will and reason". But those things that lack reason tend to an end, by natural inclination, as being moved by another and not by themselves; since they do not know the nature of an end as such, and consequently cannot ordain anything to an end, but can be ordained to an end only by another [...]. When a man of himself acts for an end, he knows the end: but when he is directed or led by another, for instance, when he acts at another's command, or when he is moved under another's compulsion, it is not necessary that he should know the end. And it is thus with irrational creatures".

13 Pagden and LaWrence (1991) p. 249.

14 Pagden and Lawrence (1991) p. 247. It is unclear to me whether the English translation of "dominium est ius" as "dominion is a legal right" (if by this we are to understand the term "legal" as a positivist conception or rights) is entirely appropriate. The Spanish translation merely establishes that "el dominio es un derecho", i.e. dominion is a right. See Pereña (1967) p. 26. It is quite clear that Vitoria is not speaking of rights granted by written decree, but rather of rights and dominion as a "natural" trait of reasoning creatures. 
and injustice are concepts pertaining to human social relations and not to any other kind of natural organism. However, even madmen, Vitoria holds, possess rights and are capable of suffering injustice; and children likewise "formed in the image of God" and existing not "for another's use, like an animal, but for [themselves]" possess dominion ${ }^{15}$.

Vitoria further challenged the use of the Aristotelian notion of natural slavery by engaging its very definition. To the question of whether "the barbarians are insufficiently rational to govern themselves" he noted that Aristotle's concept of natural slavery did not imply that "such men thereby belong by nature to others and have no rights of ownership over their bodies and possessions (dominium sui et rerum $)^{16}$ [...] What [Aristotle] meant to say was that such men have a natural deficiency, because of which they need others to govern and direct them [...] He certainly did not mean by this that [certain] men had a legal right to arrogate power to themselves over others on the grounds of their superior intelligence, but merely that they are fitted by nature to be princes and guides" 17 .

It is possible that, inasmuch as he wished to establish sovereign and equal status to the communities of the Indies, Vitoria was splitting hairs in his interpretation of Aristotle. It is nonetheless worthy of note that his discourse is directed at undermining a perspective that easily placed the Spanish Crown in a position of natural domination based on forceful and apparently cogent philosophical grounds. But this he overtly denies by asserting the most fundamental natural rights of men, and distinguishing these from those other human traits that permit men to govern others. Hence, the existence of men of superior capacity for leadership did not naturally transform others into "natural" slaves, into beings dispossessed of rights and dominion. In this view, such men did not in fact cease to be humans formed in the image of God. Vitoria logically argued that even supposing "these barbarians are as foolish and slow-witted as people say they are, it is still wrong to use this as grounds to deny their true dominion; nor can they be counted among the slaves" 18 . The principle that no man is naturally superior to any other man in any elemental way, a constitutive tenet of Vitoria's theory of the state, has thus acquired here significance for his view of the international order as being composed of communities of equal standing and dignity despite differences in cultural or religious practices. His virtually "anthropological" observation of indigenous society takes this view further.

[...] They are not in point madmen, but have judgment like other men. This is self-evident, because they have some order (ordo) in their affairs: they have properly

\footnotetext{
15 Pagden and Lawrence (1991) p. 249.

16 Vitoria adds: "Such slavery is a civil and legal condition, to which no man can belong by nature". PAGDEN AND LAWRENCE (1991) p. 251.

17 Pagden and Lawrence (1991) p. 251.

18 Pagden and Lawrence (1991) p. 251. It is interesting to note that in a passage preceding this one, Vitoria refers to a segment of his countrymen in pejorative terms. It would seem an attempt, for a brief instant, to take the natural slavery thesis toward "inner scrutiny" by arguing that one could find in Spain men who fit such status: "Thus if they [the Indians] seem too insensate and slow-witted, I put it down mainly to their [...] barbarous education. Even amongst ourselves we see many peasants who are little different from brute animals". Pagden and Lawrence (1991) p. 250.
} 
organized cities, proper marriages, magistrates and overlords (domini), laws, industries, and commerce, all of which require the use of reason. They likewise have a form of religion, and they correctly apprehend things which are evident to other men, which indicates the use of reason ${ }^{19}$.

Vitoria's immediate conclusion is that "before arrival of the Spaniards these barbarians possessed true dominion, both in public and private affairs" adding that "it would be harsh to deny to them, who have never done us any wrong, the rights we concede to Saracens and Jews, who have been continual enemies of the Christian religion" ${ }^{20}$. Urdánoz has rightly taken this to mean that Vitoria's argument was directed at demonstrating that the Indians "possess that degree of human dignity corresponding to free and inviolable individuals, and from which emerge the fundamental rights and duties inherent in all human beings" 21 . To this extent Vitoria had argued that the communities of the New World were composed of men and, most importantly, of men possessing rationality, the capacity for self-government and, hence, dominion in every sense. This was the first vital blow to those philosophical ruminations aimed at depriving indigenous societies of all forms of dominion. The problem, however, did not stop at this point. Vitoria's attack on the philosophy of natural slavery would have to also include a thoroughgoing position against religious doctrine and the idea that "sin" and religious "infidelity" were grounds for war.

\subsection{Sinners And Infidels}

The position that infidels and sinners forfeit dominion had been advanced by medieval thinkers such as John Wycliff (c.1330-1384) and Richard Fitzralph (c.12951360) as Vitoria himself noted. Wycliff maintained "No one is a civil master while he is in a state of mortal sin" 22 . This assertion, Vitoria explains, stems from the idea that "the title to any dominion is grace". Those who live in a condition of mortal sin may not thus exercise dominion over anything and, as Fitzralph had maintained, such dominion as held by sinners is hence "condemned" by God ${ }^{23}$.

In passing, it is interesting to note that this very idea of divesting the natives of dominion was similarly held by other European writers later in the seventeenth century when attempting to justify expansion into the territories of those aboriginals who, in their view, had sinned against the laws of nature in varying ways or were simply infidels possessing no rights. Sir Edward Coke, in La Septieme Parts des Reports (1671), maintained that:

All Infidels are in law perpetui inimici, perpetual enemies (for the law presumes not that they will be converted, that being a remota potentia, a remote possibilitie) for between them, as with the devils, whose subjects they be, and the Christian, there

\footnotetext{
19 Pagden and Lawrence (1991) p. 250.

20 Pagden and Lawrence (1991) pp. 250-251.

21 URDÁNOZ (1967) p. LXX.

22 Cited in Pagden and Lawrence (1991) p. 240.

23 Pagden and Lawrence. (1991) p. 240.
} 
is perpetual hostiltiy, and can be no peace... If a Christian King should conquere a kingdom of an Infidel, and bring them under his subjection, there ipso facto the lawes of the Infidel are abrogated, for that they be not only against Christianitie, but against the law of God and nature, contained in the Decalogue ${ }^{24}$.

The proposition of abrogating the laws of the conquered or of subjecting them to violence because of perceived offences against the laws of nature was a contention held closely even, as we have seen, by Hugo Grotius. Such attitudes, also present in a number of Spanish writers (such as Sepúlveda) in fact preserved the medieval religious determination of aggressiveness toward infidels. It was usually with a degree of aversion and animosity, as the passage above illustrates, that a number of European writers pondered the realm beyond their frontiers. Such attitudes clearly hark back to the era and millenarian sprit of the Crusades. In the eleventh century, Robert the Monk, chronicler of the First Crusade (1042-1099), had sketched out a view of the infidels.

From the confines of Jerusalem and the city of Constantinople a horrible tale has gone forth and very frequently has been brought to our ears; namely, that a race from the kingdom of the Persians, an accursed race, a race utterly alienated from God, a generation, forsooth, which has neither directed its heart nor entrusted its spirit to God, has invaded the land of those Christians and has depopulated them by the sword, pillage, and fire; it has led away a part of the captives to its own country, and a part it has destroyed by cruel tortures; it has either entirely destroyed the Churches of God or appropriated them for rites of its own religion. They have destroyed the altars, after having defiled them with their uncleanliness ${ }^{25}$.

In any case, the re-emergence of the idea of the "sinner" and "infidel" in sixteenth century Spain led Vitoria to utilizing the notion of Thomistic natural right as a conceptual weapon against claims justifying unlimited imperial aims. Vitoria's refutation involved a careful analysis of a number of medieval texts and of the Holy Scripture. However, the most forceful argument set forth in De Indis against the idea of mortal sin as relieving men of dominion and rights turned on the concept, once again, of natural dominion.

On the question of sin, Vitoria begins by noting that writers such as Fitzralph and Wycliff seem to be speaking of the deprivation of civil dominion or ownership. If this is the case, Vitoria continues, then it would follow that sinners do not possess natural dominion either. His immediate conclusion, nevertheless, is that the logic of this line of reasoning is utterly false.

Natural dominion is a gift of God just as civil ownership is, or indeed even more so, since civil ownership clearly belongs to human law; therefore if a man were to lose civil ownership by offending God, by the same reasoning he would lose is natural

24 Cited in Tuck (1999) p. 123.

25 Munro (1931) p. 330. 
dominion; but the proof that this is false is that the sinner does not lose his dominion over his own acts and body ${ }^{26}$.

The observation that sinners do not lose control over their acts (the ability to make choices, especially moral choices, an indication, hence, of the free will operating in them) was a clear indication that all men preserve an indestructible nature or essence granted by Divine will to all rational creatures. The fact of sin, in this view, might be more a matter of rational choice or natural free will appropriate to the nature of man than a condition which thereby annihilates his essence, natural potencies, and hence dominion. To this effect, Vitoria immediately notes:

The opponents' argument that all dominion is formed in the image of God may be turned round on itself: for man is the image of God by his inborn nature, that is, by his rational powers. Hence he cannot lose his dominion by mortal $\sin ^{27}$.

Indeed, $\sin$ is but a condition correlative to reason to the same extent that performing acts culminating in the good. Suggestions underscoring the deprivation of dominion on such grounds as those described above, he added, were "manifestly heretical" for "the Lord maketh his sun to rise on the evil and the good, and sendeth rain on the just and on the unjust (Matt. 5:45), and so he too gives his temporal goods to the good and the bad"28. Clearly, the suggestion is derived, as Carro has stated, from the arguments set forth years before in De potestate civili whereby he established that civil power is a natural phenomenon common to both believers and infidels ${ }^{29}$. This line of reasoning is equally present in his two lectures on The Power of the Church (De potestate ecclessiae, 1532-1533) wherein he makes the important distinction between two juridical orders, natural law and human law (parts of the natural order of man), and Divine law (part of the spiritual order of man), thus establishing the sovereignty of both realms. Following the same logic this effort is articulated in similar fashion, as we shall see further below, when discussing the power of the Church in the matters of the Indies.

On the question of infidelity, Vitoria ponders the premise, contained in Pope Boniface's decretal, Cum secundum leges (Sext. 5. 2. 19), that heretics, and therefore infidels "who are no better," may also lose dominion and may have their goods "confiscated ipso iure" 30 . Drawing immediately upon Aquinas (ST II-II. 10.10), he denies the assertion ${ }^{31}$.

\footnotetext{
26 Pagden and Lawrence (1991) p. 242.

27 Pagden and LaWrence (1991) p. 242.

28 Pagden and Lawrence. (1991) p. 243.

29 CARro (1947) p. 116.

30 Pagden and LaWrence (1991) p. 243.

31 Vitoria is referring here to the following passage in Aquinas' Summa Theologica: “[...] we must observe that dominion and authority [in a political or legal sense, but not in its natural meaning] are institutions of human law, while the distinction between faithful and unbelievers arises from the Divine law. Now the Divine law which is the law of grace, does not do away with human law which is the law of natural reason. Wherefore the distinction between faithful and unbelievers, considered in itself, does not do away with dominion and autho-
} 
Proof may be given, he maintains, by examining the Holy Scripture and by using reason. As regards the former, he notes:

[We may refer to the Holy Scripture], which often calls unbelievers such as Sennacherib, Pharoah, and others 'kings'; Paul (Rom. 13:1-5) and Peter (I Pet. 2:13-14, 18) gave orders to obey the rulers, who in their day were all unbelievers, and ordained that servants should obey their masters; Tobit ordered a kid to be returned to the pagans because he thought it was stolen (Tobit 2:11-14), which he would not have done if the pagans have no right of ownership ${ }^{32}$.

By way of reason, Vitoria adds, it is clear that unbelief does not do away with natural or human law; all forms of dominion derive from either of these two realms of law, the natural and the written, and thus it is incumbent upon us to understand that they may not be extinguished by an absence of faith ${ }^{33}$. This position is again referring to the distinction between the spiritual and natural spheres in human life that I have outlined above. The two spheres may be seen as complementary aspects of the essence of the individual. Coleman, in her commentary on Aquinas, has similarly expressed this idea by referring to the relationship between grace and the intellective powers of man in the pursuit of perfection and of knowledge of God as "the ultimate good". "Intellective powers," she writes, "need fortification, grace added to nature. Hence, Aquinas's famous dictum that grace does not destroy nature. But grace presupposes nature, and faith presupposes natural knowledge [...]"34.

Vitoria was quick to thus assert the natural and legal, the public and private, dominion of the barbarians considering that neither sin nor infidelity could be adduced by Christians as legitimate arguments for dispossessing them of their public and private goods. By affirming the rational character of the aboriginals (and hence the rights pertaining to them because of this), and by separating the natural and spiritual realms Vitoria managed to construct, thus far, the independent nature of these newlydiscovered non-European communities. The most important line of reasoning, however, was his defeat of the assertion of the barbarism or animal-like character of the Indians so characteristic of the natural slavery arguments set forth by Sepúlveda and even the Scottish nominalist, John Mair, who sought to justify the occupation of the West Indies on these very grounds ${ }^{35}$. To assert their humanity by way of a vindication of their rational nature was the first and most fundamental step in constructing the "sovereign"

rity of unbelievers over the faithful". (ST II-II. 10.10). Aquinas later emphasises, however, that dominion over the faithful by conversion may be taken away, in defence of the interests of the latter. The Church, he adds, sometimes does this and sometimes not, depending upon the circumstances.

32 Pagden and Lawrence (1991) p. 244. The Spanish language version preserves a further passage: "Furthermore, more grave than the sin of infidelity is hate of God; and nonetheless hate does not prevent one from being a true master; ergo, neither does infidelity". The translation is mine. In the original Spanish the passage reads: "Además, porque pecado más grave que la infidelidad es odiar a Dios; y sin embargo el odio no impide el ser verdadero señor; luego tampoco la infidelidad". See Pereña (1967) p. 20.

33 Pagden and Lawrence (1991) p. 244.

34 Coleman (2000) p. 92.

35 Tuck (1999) pp. 41, 67. 
status and equality of their societies. The construction of that sovereign status results in the idea of the self-sufficient communitas perfecta, the self-contained community of men, engaging in social pursuits in accordance with their own customs, resembling, in a number of respects, the structure and the emerging Renaissance view of the state.

In any case, the natural slavery arguments prompt us to recall an endemic feature of modern international affairs, viz. the question of cultural diversity, and of the civilizational differences between dominant Western states and their relations with non-Western communities. The nineteenth century inception of the "standard of civilization" formed the criterion for imposing, as Brown has put it, "restrictions upon the sovereignty of 'uncivilized' non-European powers whose legal codes and general conduct of affairs did not meet European standards" 36 . The drive for the political conversion of the non-European world during this period is reminiscent of the logic of empire that moved the Spanish conquerors forward into the New World, armed not merely with swords but with the much sharper philosophical justifications of the jurists and theologians. Notwithstanding the secondary "humanitarian effects" of imperial intervention in a number of cases, as Brown illustrates in his text, the underlying motivations of empire were linked to power political considerations and economic interests in an international system marked by the expansion of the European balance of power regime to the far corners of the globe. In De iure belli, Vitoria condemned such motivations by stating "Non est iusta causa belli amplificatio imperii" ('enlargement of empire cannot be a cause of just war'), which was preceded by the assertion "causa iusti belli non est diversitas religionis" ('difference of religion cannot be a cause of just war') $)^{37}$.

\section{LIMITING EMPIRE AND AUTHORITY OVER THE WORLD}

Urdánoz referred to the concept of universal dominion, the assertion that a particular authority such as the pope or emperor might legitimately rule over the world, as a "false image" of international society ${ }^{38}$. The root idea may be found, Wight has suggested, in King Alexander III of Macedon's replacement of the image of the Aristotelian city-state by world empire, thereby bringing into unity a perceived brotherhood of mankind. It is presumably the first known statement of its kind in the West that later reemerged in Christian thought under the affirmation of the presumed universal jurisdiction of the pope ${ }^{39}$. This was an attempt to bestow political continuity, in new guise, to the deceased Roman Empire through the medieval allegiance to a sacrum imperium. Popes Gregory VII (c.1020-1085), and Innocent III (c.1160-1216) had forged the ideological basis of this imperium totius mundi, which had been later championed in the twelfth and

\footnotetext{
36 Brown (2002) p. 139.

37 Pagden And Lawrence (1991) pp. 302, 303.

38 Autho (1967) p. LXXXII.

39 Wight (1992) pp. 83-84.
} 
thirteenth centuries by numerous glossators and decretalists, including the Italian lawyer and Roman law commentator, Bartolus (c.1313-1357) ${ }^{40}$.

True to this idea of universal monarchy, so extolled by Dante, the Papal Bulls of Alexander VI (1431-1503) had conferred upon Spain political dominion over the vast territories of the New World. The well-known Requerimiento (1510), read to the Indians upon arrival, established the sovereign authority of the Spanish Crown and the pope over the indigenous communities and, at least theoretically, over the world itself. Any denial of the verity of these statements or, more to the point, any refusal to accept the terms upon which the Spaniards had entered their realms would meet with brutal retaliation.

But, if you do not do this [accept the authority of Spain and Church], and maliciously make delay in it, I certify to you that, with the help of God, we shall powerfully enter into your country, and shall make war against you in all ways and manners that we can, and shall subject you to the yoke and obedience of the Church and of their Highnesses; we shall take you and your wives and your children, and shall make slaves of them, and as such shall sell and dispose of them as their Highnesses may command; and we shall take away your goods, and shall do you all the mischief and damage that we can, as to vassals who do not obey, and refuse to receive their lord, and resist and contradict him; and we protest that the deaths and losses which shall accrue from this are your fault, and not that of their Highnesses, or ours, nor of these cavaliers who come with us. And that we have said this to you and made this Requisition, we request the notary here present to give us his testimony in writing, and we ask the rest who are present that they should be witnesses of this Requisition ${ }^{41}$.

The Spaniards would not be, however, the only European nation to lay claim upon foreign territories and peoples. Grotius, contrary to what many believe, had also justified incursions into the New World. Although not clearly an argument against infidelity per se it was one which took into consideration "barbarous customs" and hinged upon the tradition of medieval thought in this respect. And to this very effect, Grotius argued consciously against the viewpoint embraced by Vitoria in De Iure Belli ac Pacis (Book II, Ch. 20).

So far this opinion agrees with that of Innocentius and others, who maintain all war to be lawful against those who have renounced the ties and law of nature. An opinion directly the reverse is held by Victoria, Vasquez, Azorius, Molina, and others, who deem an aggression done to a prince, his government, or his subjects, or civil jurisdiction over the aggressor, the only justifiable warrant for inflicting punishment, particularly the punishment of hostilities. For they suppose punishment to be an effect purely arising from the authority of civil law, whereas,

40 Autho (1967) p. LXXXIV.

41 Parry And Keith (1984) pp. 288-290. 
according to the proofs established in the beginning of this treatise, it was shewn to be a right resulting entirely from the law of nature ${ }^{42}$.

Grotius' argument, however, does not entirely capture Vitoria's thought on the issue of punishment in war, which is but the manifestation of a legitimate act of restoration of an order of justice between states. This is the concept of the doctrine of the just war and of the dual sources that bring it to life: the public authorization (the governing authority) of violence and natural right or justice. By contrast, Grotius has argued here that punishment is an effect solely of "civil authority" in Vitorian thought, rather than an effect, as he held, arising from the law of nature itself. Nevertheless, in De Iure Belli (1539) Vitoria's argument on this question is that the only institution authorized to wage and declare war is public or governing authority as the "authorized representative of the commonwealth" 43 . At the same time, "the sole and only just cause for waging war is when harm [sic] has been inflicted" 44 . In this manner, "punishment" or the "right" to conduct hostilities do arise from a particular order of the law of nature that concerns justice (in the Thomistic sense). Grotius seems to have separated, consciously or by way of error, these two notions in an apparent effort to buttress his position on the character of natural law.

Indeed, as Tuck has emphasized, Grotius' view of natural man or of the state of nature was one which underscored the existence of a rather thin morality, or minimal sociability, in civil society. Men were seen as possessing, in a manner not dissimilar to Hobbes' view on the matter, an inclination toward self-interest and self-preservation (an idea that countered the Thomistic assertion of man as possessing a natural inclination toward the good), and it was this that formed the foundation of Grotius' own account of rights. ${ }^{45}$ This implied that all private individuals could legitimately acquire as many goods as possible so long as, in doing so, the goods of others were not usurped. As Tuck's study demonstrates, this meant that the Dutch had a fundamental right to engage in foreign trade and, ultimately, to annex territories in the non-European world. ${ }^{46}$ The infliction of violence (in the sense of punishment) against non-Europeans, moreover, was supported by Grotius' further appeal to the Aristotelian natural slavery argument I have outlined above. ${ }^{47}$ The idea of punishment and the legitimate foundations of war, in the context of relations between Europeans and non-Europeans, were here linked to a naturalistic (egoistic) conception of man and to the parallel notion that others were well suited to being governed by those with a natural right to do so. Grotius seems to have placed much greater emphasis, however, on the question

\footnotetext{
42 Grotius (2001) pp. 207-208.

43 See Pagden and Lawrence (1991) pp. 300-301.

44 Pagden and Lawrence (1991) p. 303. Again, the English translation speaks of "harm". The original Latin uses the term "iniuria" which implies both "injury" and "injustice": "Una sola causa iusti belli est, scilicet iniuria accepta”, Pereña ed. (1981): Francisco de Vitoria. Relectio de Iure Belli o Paz Dinámica: Escuela Española de la Paz, Primera Generación 1526-1560, Corpus Hispanorum de Pace, vol. VI (Madrid: Consejo Suprerior de Investigaciones Científicas), p. 126. Hence, the grounds for war entail being subjected to a prior action that has "harmed" the commonwealth through its inherent injustice.

45 On this see Tuck's chapter on Hugo Grotius. Tuck (1999) pp. 78-108. passim.

46 Tuck (1999) p. 89.

47 Tuck (1999) p. 89.
} 
of property and jurisdiction over lands which, by natural right could be exploited by newly arrived visitors. The implication of this argument is summed up by Tuck.

[In Grotius' view] there is a general natural right to possess any waste land, but one must defer to the local political authorities, assuming they are willing to let one settle. If they are not, of course, then the situation is different, for the local authorities have violated a principle of the law of nature and may be punished by war waged against them. ${ }^{48}$

The philosophical basis for expansion, that unrelenting right to self-preservation through the acquisition of property, was not wholly linked to the idea of sin or infidelity, but it is a perspective that relied upon the crucial distinction between the Europeans who were informed by natural law (and who were aware of the rights of nature handed down to them by Divine Will) and those irreligious cultures deprived of such Christian wisdom.

It becomes quite apparent that the human consequences of such injunctions, as those of the Requerimiento were at the heart of Vitoria's concerns, and it was incumbent upon him to define the limits to be placed on the aims and methods of imperial expansion. In this respect, the initial arguments of De Indis had established, as outlined above, the sovereign status and dignity of these communities. However, in drawing once more upon natural law precepts (among others), his second purpose was to disallow empire as a rightful method of communication with the "barbarians". Empire or dominion, over others could not be justified by what he considered arbitrary and utterly false claims (chief among these the claims to universal dominion by pope and emperor). The achievement of these two initial purposes would generate an image of the globe wherein all communities fall upon a common plane of equality and sovereignty.

\subsection{Limiting Imperial Authority}

In this respect, the second part of De Indis (in what Vitoria referred to as the first "unjust title" of rule) asks whether the emperor may be considered master of the world. The possession of such dominion could theoretically only be bestowed upon someone by natural law (natural right), divine law or human law. "But the emperor," Vitoria claimed "is not master of the world by any of these" 49 . His first assault on this view drew upon Thomistic iusnaturalism in its contention that all men are free "other than from the dominion of fathers or husbands, who have dominion over their children and wives in natural law (ST I. 92. 1 ad2; I. 96. 4); therefore no one can be emperor of the world by natural law" ${ }^{50}$. This statement may seem to contradict Vitoria's theory of the state, which establishes the natural character of political dominion and which may, in this manner, said to belong to natural right. But Vitoria, drawing upon Aristotle and Aquinas on this question, reminds us that while such dominion may indeed have its origin in nature, its

\footnotetext{
48 Tuck (1999) p. 106.

49 Pagden and Lawrence (1991) p. 253.

50 Pagden and Lawrence (1991) p. 254.
} 
institutionalization is not effected by nature itself but by human enactment. Political dominion and supremacy are expressions of positive law, as Aquinas had stated, and as such are the materialization of human decisions regarding authority. ${ }^{51}$ If this were not, in fact, the case (that is, if such jurisdiction were only by natural right) "there would be no good reason why imperial dominion should belong to the Spanish rather than to the French" 52 . In this respect, Vitoria is constructing the idea of a world comprised of a multiplicity of powers, a view quite consistent with the Spanish political theory of the state, whose origin is of natural law, but whose actual materialization and existence are wholly dependent upon human volition and legal enactment. Thus far, there had not existed any such enactment determining this mode of world jurisdiction. ${ }^{53}$

Vitoria returns to this question by pondering the possibility that such a right could exist by divine law. This meant examining a number of biblical sources and turning, once again, to Aquinas. A few points are worth noting. One will not be able to find, Vitoria pronounces, any indication in the Holy Scripture of the existence of emperors or lords of the world "before the advent of Christ". And while Aquinas seems to establish that God had bestowed imperial power upon the Romans owing to "their justice and patriotism and excellent laws (De regimine principum III. 4)" we should not, by virtue of this, understand that they held imperial status by "divine institution" or "livery of seisin" (transfer of possession). Rather, it should be understood that "divine Providence brought it about that they should obtain universal empire by some other right, such as just war or some other way" 54 . But what of Christ who had been granted mastery of the Earth by his human nature according to Mathew's verse: "All power is given unto me in heaven and in Earth (Matt: 28: 18)"? According to Vitoria's text, Aquinas' position was apparently that Christ had been a true lord of the world (De regimine principum III. 4) with Augustus as his regent in temporal but not spiritual matters. This meant that if Christ had been true master of the world, it follows from this that Augustus and his successors would also enjoy the same status. His response once more drew upon Aquinas.

But this too is quite invalid as an argument. First it is by no means certain that Christ was temporal master of the world according to his humanity - more probably not, since the Lord himself seems to have asserted 'My kingdom is not of this world' (John 18: 36), from which St Thomas deduced in De regimine principum III. 13

\footnotetext{
51 The text on this question thus reads: "Aristotle puts it this way: power is of two kinds, family power like that of a father over his sons or a husband over his wife, which is natural, and civil power, which may indeed have its origin in nature and may thus be said to belong to natural law, since as St Thomas says 'man is a civil animal' (De regimine principum I. 1) but which was undoubtedly not instituted by nature, but by enactment (lex)”. Pagden and Lawrence (1991) p. 254.

52 Pagden and Lawrence (1991) p. 254.

53 In De potestate civili, Vitoria was clear in stating that the world could elect (i.e. via human enactment) a monarch or a world-governing authority: "The human race," he maintained, "once had this power of electing a single supreme prince, in the beginning before the division [of races]; therefore, since this power was part of natural law, it must still exist". Pagden and Lawrence (1991) pp. 31-32. The Spanish language translation refers not to "races" but to "peoples". See Vitoria (1998) p. 40.

54 Pagden and Lawrence (1991) pp. 254-255.
} 
that Christ's dominion is directly ordained for the salvation of the soul and spiritual goods, though it is not excluded from temporal things insofar as they are ordained for spiritual ends. It is thus clear that St Thomas did not hold the opinion Christ's kingdom was of the same type as civil and temporal kingship, although for the purposes of redemption He had complete power even in temporal matters. Apart from this purpose, however, he had no power. ${ }^{55}$

The matter then turned on human law once again. Vitoria established that no such legal enactment exists, and that even if this were the case such an enactment would not be licit in any meaningful sense because it presupposes an inexistent prior jurisdiction (by natural or divine law). Such an enactment would, of course, and for this very reason, not become binding upon subjects over which there exists no authority whatsoever. And even if such jurisdiction actually existed it would not legitimately entitle the emperor to confiscate property and make use of realms arbitrarily. "Such a right," he concluded, "does not include the license to turn whole countries to his own use, or dispose at whim of townships or even estates. From everything that has been said, therefore, it is clear that the Spaniards could not invade these lands using this first title" 56.

\subsection{Limiting Papal Authority}

The problem of limiting papal authority, and of denying the parallel claim that Spain was acting on its behalf in the Indies, involved the implementation of an argument virtually identical to the one used on the subject of infidelity and of the non-temporal dominion of Christ: it was the suggestion that the pope possesses primarily spiritual, but not temporal, authority; and that such authority may be exercised primarily over Christian subjects.

Vitoria briefly reviews a number medieval authors that uphold the view of Papal dominion over the earth, noting that apparently even Aquinas, in his commentary on Peter Lombard's Sentences, attributes to the pope, Christ's vicar, "the two summits of power, that is both secular and spiritual" 57 . The various medieval texts on this issue had allowed the Spanish to deduce, as Vitoria put it, that the pope was empowered to grant the Spanish kings authority over the indigenous communities, and that, even if this were not the case, their unwillingness to accept his temporal dominion would meet with a justifiably waged war upon them and the imposition of Christian rulers. In a clear reference to the historical facts of Spanish empire and to the Requerimiento, Vitoria adds:

First the pope ceded these countries to the kings of Spain, then the barbarians were informed that the pope was the vicar and lieutenant of God on earth, that they

\footnotetext{
55 Pagden and Lawrence (1991) p. 256. Similar statements may found in De potestate civili, pp. 27-29.

56 Pagden and Lawrence (1991) p. 258.

57 Pagden and Lawrence (1991) p. 259.
} 
should therefore recognize him as their superior, and that if they refused war could justly be declared upon them, their countries conquered, and so forth. ${ }^{58}$

But the opposite, he maintained, is rather the truth of the matter. The denial of such dominion was the position of a number of medieval thinkers, ${ }^{59}$ and it is logical to sustain, he continues, that if Christ had not possessed temporal dominion, then certainly the pope could not attribute to himself something which his master did not have. "Yet these men [the medieval writers] attribute to the supreme pontiff what he himself has never recognized, indeed, popes have frequently asserted the opposite [...]"60 Quite to the point, and appealing to his argument against the authority of the emperor, Vitoria stresses the notion that the pope does not possess universal dominion by either natural or human law, and that if we consider divine law, all that may be said to exist is indications that papal dominion is of an exclusively spiritual nature. And such temporal power as he may, indeed, possess is ordered merely toward "the administration of spiritual things" 61 . This meant that the pope might "infringe" any civil laws if these, for example, promote sinful deeds. He may equally act as intermediary and judge between warring Christian princes and "on occasion" depose or designate them as rulers, "as has sometimes happened" 62 . In respect of unbelievers, the pope exercises no power over them (not even spiritual power), "nor can he excommunicate them, or prevent them from marrying within the degrees of consanguinity prohibited by divine law" 63 .

There are two crucial ideas operating at this stage in De Indis: that by none of the known laws, as in the case of the emperor, does the pope exercise any sort of political dominion, except in the spiritual order of life and only in issues that pertain to the adminis-

\footnotetext{
58 Pagden and LaWrence (1991) p. 259.

59 Vitoria thus notes: "This is the conclusion of Torquemada, summa de ecclesia II. 113; of Johannes Andreae in his Novella on the decretal Per uenerabilem (X. 4. 17. 13); and of Huguccio of Pisa in his commentary on the canon Cum ad uerum (Decretum D.96. 6). The learned Innocent III clearly stated that he had no power in temporal matters over the king of France in his decretal Per uenerabilem (X. 4. 17. 13), and this is also the express determination of St Bernard in De consideratione ad Eugenium III 2. 9-11". Pagden and Lawrence (1991) p. 260. The translator of this edition seems to have unfortunately attributed to Innocent III an attitude expressed by Innocent IV. The Spanish translation explicitly refers to the latter. García y García cites pope Innocent the IV (d.1254), in his Super quinque decretalium (published much later in 1570), arguing that occupied lands could not be legitimately taken over by others: "It was therefore allowable for anyone to occupy what was unoccupied but not that which was already occupied by others because to have done so would have offended that law of nature which applies to every man and prevents him from doing to others what he would not have others do to him”. Cited in García y García (1997) p. 26. Innocent III (1160-1216), by contrast, had imposed Otto IV upon Germany, amidst protests of interference in its affairs, and had threatened those who did not acknowledge him as Roman king with excommunication. However, Vitoria would later draw upon Innocent IV to justify intervention as a means for protecting the innocent natives from tyrannical rulers who enforce rituals that result in unjustifiable death. Only on account of this violation of the law of nature (a clear reference to that part of natural law concerning justice), and only in this respect, was Innocent IV's position acceptable. See Pagden and Lawrence (1991) p. 288.

60 Pagden and Lawrence (1991) p. 260.

61 Pagden and Lawrence (1991) p. 261.

62 Pagden and Lawrence (1991) pp. 261-262.

63 Pagden and Lawrence (1991) p. 261.
} 
tration of the Church as an ecclesiastical authority; and even in this latter order, his dominion is only over Christian subjects and not over the communities of the New World.

\subsection{Matters of Faith, Nature and Discovery}

Vitoria went a few steps further, however, in his discussion of dominion and the reasons for which war against the Indians could be legitimately conducted. As a corollary to the preceding arguments he examined the claims arguing for the recourse to violence based upon considerations centering on unwillingness to accept the Christian faith, on sins against nature, and on the idea of a right of discovery. His statements on the first two questions are indeed variations on the theme of infidels and sinners discussed above. However, the questions are posited in a different manner.

To the denial of sin and infidelity as licit motives for war, is also the denial of the claim that not accepting the faith, even after it has been preached to the aboriginals, constitutes grounds for such violence. Indeed, some even believe that the Indians are obliged to accept the Christian faith. Aquinas had referred to this subject matter in his Summa Theologica, and maintained that there existed two paths of unbelief: by way of "pure negation" (i.e. by simply not having the faith due to circumstances of ignorance), and by "opposition" to the faith accompanied by a refusal to hear it. For Aquinas this latter aspect was constitutive of $\sin$ (and Vitoria later in De Indis insists on a right to propagate religious beliefs). However, unbelief in the first manner he saw in the following light:

If, however, we take it by way of pure negation, as we find it in those who have heard nothing about the faith, it bears the character, not of sin, but of punishment, because such like ignorance of Divine things is a result of the sin of our first parent. If such like unbelievers are damned, it is on account of other sins, which cannot be taken away without faith, but not on account of their sin of unbelief. Hence Our Lord said (John 15:22) "If I had not come, and spoken to them, they would not have sin"; which Augustine expounds (Tract. lxxxix in Joan.) as "referring to the sin whereby they believed not in Christ". (ST II-II 10.1). ${ }^{64}$

Aquinas' statements were of vital importance for Vitoria because he was countering once again the idea that the barbarians were committing a sin of unbelief (now based on "vincible ignorance" of Christ and the Christian faith). He argued, however, that for ignorance to be vincible a form of negligence such as the unwillingness to merely listen must accompany it. ${ }^{65}$ Likewise, to decide that ignorance is invincible all that is required is that "a man has taken every care humanly possible to find out the truth, even if he happens to be otherwise in a state of sin". His conclusion was as follows:

64 Aquinas immediately adds: "To have the faith is not part of human nature, but it is part of human nature that man's mind should not thwart his inner instinct, and the outward preaching of the truth. Hence, in this way, unbelief is contrary to nature". (ST II-II 10. 1). Vitoria later draws upon this notion in the concept of the right to preach religion.

65 Pagden and Lawrence (1991) p. 268. 
The barbarians who have never received any news of the faith or Christian religion will be damned for their mortal sins or their idolatry; but not for the sin of unbelief, as St Thomas says (ST II-II 10. 1). If they were to do their best to live well according to the law of nature, it is a fact that the Lord would take care to enlighten them concerning the name of Christ. But it does not follow from this that, if they live evil lives, their ignorance or lack of belief in baptism and the Christian religion should be counted against them as a $\sin ^{66}$

This assertion allowed Vitoria to further claim that the communities in question were not obliged to accept the Christian faith on first pronouncements, a clear reference to the Requerimiento. They could not be accused of sin before simple pronouncements, "unaccompanied by miracles or any other kind of proof or persuasion..." 67 There would be no reason, indeed, for them to believe the Christians rather than the Saracens since they would, furthermore, not understand the nature of the men who had come to preach this new religion for, as Aquinas had established, "things which are of faith visibly and clearly belong to the realm of the credible; the faithful man would not believe them unless he could see they were credible, either by palpable signs or by some other means (ST II-II 1. 4)" 68 . The act of preaching the faith entailed obligations on the part of those spreading the word of God; persuasion had to be conducted peacefully, with rational arguments. ${ }^{69}$ However, Vitoria explained, there was no evidence that the faith had been preached in any "exemplary" manner; he had only known of "provocations, savage crimes, and multitudes of unholy acts" by the Spanish. ${ }^{70}$

Nonetheless, even if the faith had been announced "probably and sufficiently" this still remained an inadequate reason for engaging in war and usurping their property; as Aristotle had shown, "belief is a matter of the will, but fear considerably diminishes the freedom of the will" 71 . Vitoria was attempting to demonstrate that methods of violence and intimidation were not proper means for achieving conversion to the faith; that those

66 Pagden and Lawrence (1991) p. 269

67 Pagden and Lawrence (1991) p. 269.

68 Pagden and Lawrence (1991) pp. 269-270.

69 Pagden and Lawrence (1991) pp. 270-271.

70 Pagden and Lawrence (1991) p. 271.

71 Pagden and Lawrence (1991) p. 272. Aristotle had posed the question in the following manner when speaking of "things" or actions that involve the will: " $[. .$.$] with regard to the things that are done from fear$ of greater evils (e.g. if a tyrant were order one to do something base, having one's parents and children in his power, and if one did the action they were to be saved, but otherwise would be put to death), it may be debated

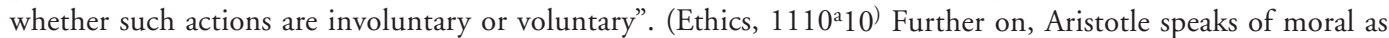
actions performed by choice (Ethics, $1111^{\mathrm{b}} 1-1113^{\mathrm{a}} 6$ ). See Aristotle (1980) pp. 48, 53-58. Vitoria addresses this issue later in the text when it is asked whether the Indians may accept a Spanish king voluntarily after it has been explained to them that being ruled by the Spanish would bring them benefits. He readily emphasises that such propositions are often articulated in an ambience of trepidation wherein "the request is made by armed men, who surround a fearful and defenceless crowd". He further explains that they already have their own masters and princes; that a people cannot seek new ones without a reasonable cause, and that, furthermore, "the masters themselves [cannot] elect a new prince without the assent of the whole people". PAGDEN AND LAWRENCE (1991) p. 276. 
who did so were acting out of self-interest, but not in the interest of God. Note that this argument is directly relevant to the idea of reason, free-will, and moral agency acting in the nature of man. The moral choices, and even the immoral choices, that man makes are naturally arrived at on the basis of his natural dominion and practical reason. Such agency is therefore tainted when articulated in conditions that thwart free will. "Hence," Vitoria held, "the barbarians cannot be moved by war to believe and accept the Christian faith, but only to pretend to believe that they accept the Christian faith, and this is monstrous and sacrilegious" 72 .

But what of sins against the law of nature (lex naturalis) and the idea that papal power could authorize Christian princes to judge and punish the misdeeds of the barbarians? Here, Vitoria is not referring to the natural rights pertaining to individuals; nor is he, as a consequence, referring to the order of justice guiding the political life of the state or to relations between them, but to certain principles governing the operations of the natural order, "natural laws" in a much looser sense. It is, as he argued, what is described by the word 'uncleanliness' in 2 Cor. 12: 21 which the Glosa ordinaria explains as pederasty, buggery with animals, or lesbianism" and other activities of similar import. It was Vitoria's view that punishing the barbarians for such sins could not proceed without a prior jurisdiction over them (a jurisdiction which, as he had already established, did not exist); that, indeed, chastisement and judgment may be rendered only "over those who have subjected themselves to the faith". Furthermore:

[...] the pope may not make war on Christians because they are fornicators or robbers, or even because they are sodomites; nor can he confiscate their lands and give them to other princes; if he could, since every country is full of sinners, kingdoms could be exchanged every day. And a further confirmation is that such sins are more serious in Christians, who know them to be sins, than in the barbarians, who do not. Besides, it would be extraordinary that the pope should be able to pronounce judgments and inflict punishment on unbelievers, and yet prevented from making laws for them..$^{73}$

Clearly, Vitoria is concerned with emphasizing an underlying principle governing the ability to effect punishment for such acts: that of jurisdiction be this spiritual or civil. Thus considered, punishment of offences requires that the indigenous communities fall legitimately under the authority of the Church (by way of credible conversion) and/or under the political and legal authority of the Spanish state (or, broadly speaking, of any other state), thereby denoting such communities as being subordinate parts of a higher authority. However, his reasoning in this regard never went quite this far. Indeed, in his earlier lecture on this problem in De temperantia (1537), Vitoria noted that pagan rulers converted to Christianity could oblige their subjects to follow the precepts of natural right and the Bible, to abandon idolatry (the suppression of this latter activity being more important and

72 Pagden and LaWrence (1991) p. 272.

73 Pagden and Lawrence (1991) p. 274. 
obligatory than all the other) and unnatural rituals, though he could not, as in the case of the Spanish, obligate them to embrace the faith or subject them to forced baptism. ${ }^{74}$ Thus, Vitoria underscored the fact that even by virtue of religious conversion a pagan prince does not lose authority over his subjects. ${ }^{75}$ In any case, the absence of such jurisdiction (which Vitoria had previously proven not to exist by any natural, divine or human law) precludes almost all forms of intervention or retaliatory measures directed against what would normally be considered (from the perspective of Christian doctrine) abhorrent forms of conduct or unacceptable cultural practices. Note that Vitoria here is not referring to the classical just war doctrine, which would involve and require an injustice or injury between discreet communities, but rather to a doctrine of intervention based on activities arising from within particular communities and which would justify interference in their internal affairs. $^{76}$

I wish to examine an additional question that Vitoria ponders in this part of his lecture, viz., the possibility that these new communities might be brought under the authority of Spanish power by a right of discovery. The conceptualization of such a right was far from being novel or without precedent. The Justinian Institutes, to which he refers in passing, had established that such a right existed.

Things become the property of individuals in many ways, for by natural law we obtain the ownership of certain things which, as we have already stated, is called the Law of Nations, and we obtain the ownership of others by the Civil Law. It is more convenient, therefore, to begin with the more ancient law; for it is evident that natural law is the older because in the course of nature it originated at the same time with the human race; and civil laws only came into existence when states were founded, magistrates appointed, and laws committed to writing for the first time. (Institutes, II. 1. 11).

Therefore, wild beasts, birds, and fishes, that is to say all creatures that exist on the earth, in the sea, or in the air, as soon as they are taken by anyone immediately become his property by the Law of Nations, since whatever formerly belonged to no

\footnotetext{
74 However, even the legitimate implementation of coercion in this regard has its limits: “[...] so long as no provocation to unrest ensues which may lead to a worse result, Christian princes can compel their nonChristian subjects to give up not only those of their sins and rituals which are against natural law, but also those which are against divine law". (The italics are mine). Pagden and Lawrence (1991) p. 222. The clause in italics is reflective of the idea of the common good as being more vital that what seem to be necessary corrective measures. It is also considered within the just war doctrine. The methods and aims of just war, for example, may be undertaken as long as the perceived outcome results in a greater good. In De iure belli Vitoria explains we should remember that "care should be taken to ensure that the evil effects of the war do not outweigh the possible benefits sought by waging it". PAgden and LaWrence (1991) p. 315. More to the point, in De potestate civili he notes that "no war is legitimate if it is shown to be more harmful than useful to the commonwealth, even if there are titles and reasons in other respects which makes the war a just one". PAGDEN AND LAWRENCE (1991) p. 21.

75 Pagden and LaWrence (1991) p. 219.

76 It is worth noting, however, that there is one clear exception to this rule: the protection of the most fundamental natural rights of individuals, as when they are subjected to rituals of sacrifice. I will discuss this in the following section on the ius gentium.
} 
one is conceded by natural reason to the first person obtaining possession of the same. (Institutes, II. 1. 12). ${ }^{77}$

The familiar concept of res nullius is clearly embraced here; and it had been argued that perhaps the Spanish could take possession of those territories by this title. Vitoria quickly tore asunder this title by the obvious fact that the aboriginals, possessing furthermore public and private dominion, already exercised authority and jurisdiction over the territories in question. Hence this title "provides no support for possession of these lands, any more than it would if they had discovered us"78. I mention Vitoria on this point because certain intellectual trends in later European thought would legitimate empire as a means for occupying and waging war upon others.

This was essentially the view of John Selden (1584-1654), the English jurist, whose Mare Clausum (1618), a rejoinder to Grotius' De iure belli ac pacis, sought in part to establish English sovereignty over the seas separating England and the European continent. His text envisioned the world as being composed of individuals who originally shared in the ownership of globe. However, Tuck's study of Selden's thought shows us that he had arrived at the conclusion that in the absence of a prior positive agreement, there was no palpable reason why "first occupation" should grant rights against others who might equally desire any territory already occupied. ${ }^{79}$ Contrary to Christian thought on this matter, Selden established that "precedent injury" was not necessary to engage in a war. Rather the need for empire or territorial aggrandizement was reason enough. As Tuck observes, "the original 'right of all men to all things' was associated in Selden's argument with a right to make war for whatever the belligerent party saw fit" ${ }^{80}$. In contradistinction to this latter assertion, Vitoria's De iure belli held that "enlargement of empire (amplificatio imperii) cannot be a cause of a just war". If this were not patently the case, he stated forcefully, "both parties in a war would have equally just cause to fight, and both would be innocent; from this it would follow that it is unlawful for either side to kill the other, and this would be self-contradictory, for it would mean that the war was just, but the killing unjust" 1 . It is quite evidently the case that one of the principal differences between Selden and Vitoria on matters of war and expansion hinges upon a radically different interpretation of the rights of existing settled communities. In his attempt to defend the English colonies in North America, Selden sought to draw extraordinary and striking conclusions from the concept of original ownership and thereby threw, intentionally or not, a sabot into the previous conceptual machinery of natural dominion thus establishing that occupied lands could be respected only by virtue of the existence of prior legal commitments between the English and the communities of the territories yet to be discovered. ${ }^{82}$ This is unquestionably a position that is at odds with

\footnotetext{
77 ScOTt (1932) p. 33.

78 Pagden and Lawrence (1991) pp. 264-265.

79 A more detailed account of Selden's thought may be found in Tuck (1999) pp. 113-120.

80 Tuck (1999) p. 119.

81 Pagden and Lawrence (1991) p. 303.

82 Tuck (1999) p. 120.
} 
Vitoria's conceptualization of the rights pertaining to the individual, and by dint of logic, to the community to which he belongs. To quote a recent scholar whose statements succinctly reflect the spirit of Vitoria's thoughts, "[...] territorial integrity and political sovereignty [...] both belong to states, but they derive ultimately from the rights of individuals, and from them they take their force" 83 . Hence, Selden's stance on matters of expansion and war is logically coherent only if the concept of man is cast into obscurity or dispensed with altogether. Imperial aspirations are more easily justified in this respect because, in this manner, questions about the moral standing of states, and their equal status (based precisely on a perceived dignity and equality between individual men) are hurled into oblivion. Such a procedure allows the question of rights between communities, and the justifications for war, to become a function merely of customary legal arrangements between them rather than the result of basing such rights on considerations of humanity.

Vitoria's arguments are undoubtedly remarkable considering the historical context in which they were set forth; the mood of the Catholic Church in the "heretical" era of Luther, the growing shadow of Reason of State, and the interests of Spanish power within and beyond Europe. In an epoch of European religious fragmentation, political intrigue, and power political competition (in the immediate rivalry between Spain and France, accompanied by the fear of the Ottoman empire), it is worthy of note that Vitoria should have initiated a doctrinal system that outlined the limits of power and political authority. In the words of one scholar, who addressed what he considers Vitoria's idealism, "(Parry, John H. and Keith, Robert G., 1984)[Vitoria] could only appeal to accepted principles as a check on the behavior of the prince, and this at a time when the moral consensus of Europe was less secure than it had been for centuries and was being weakened further by the passage of time" 84 . But it might be said that it was precisely because of such developments that Vitoria saw fit the construction, or the re-deployment, of the Thomistic doctrine of natural right from within the Dominican order.

The task of constructing sovereignty beyond the frontiers of European society involved, as argued above, depicting other non-European communities as human associations of equal status; and casting aside that "false image" of international society, which asserted various forms of universal dominion. In other words, before speaking of the rights and duties between states, it was necessary to establish that the world was in fact composed of sovereign communities. ${ }^{85}$ From this followed the logical corollary that no single state possessed authority over others; and that the exercise of power was constrained by the sovereign status of other states. The assertion of spiritual or political dominion over other communities was denied essentially on the basis of natural right: no man and no community lose dominion by infidelity; believers and infidels, who are also rational creatures, are conjoined by nature and are of the same nature. Hence, arguments that attempted to appeal to divine or human law, or to the perceived inferior and irreligious

\footnotetext{
83 WALZer (1977) p. 53.

84 Mattingly (1963) p. 292.

85 While Vitoria did not use the term "sovereignty" or "sovereign", it is nonetheless the case, that the idea is embodied in his state theory when discussing dominium and particularly the idea of the communitas perfecta.
} 
character of the new communities, were set against a system of precepts that limited their impulse toward justifying domination. To this extent, one Spanish scholar has noted that Vitoria's excursus in De Indis establishes one fundamental trait of natural right: "Natural right brings to a halt all other forms of law, even divine positive law, the foundation of the Church of Christ" 86 . Natural right in this fashion limits all other laws, and is distinguished by the fact that it is, in this respect, the standard by which all institutions may be judged.

\section{RIGHTS, DUTIES AND JUSTICE BETWEEN COMMUNITIES: THE LAW OF NATIONS}

The final section of De Indis speaks of the "just titles" by which the communities of the New World could come under foreign rule. It is easy to arrive at the apparently correct conclusion that Vitoria was opening a window of opportunity for justifying war and rule over the barbarians. However, this was the furthest of his intentions. The first indication of this lies in his careful line of reasoning which denied the medieval theocratic conception of the world and then established the sovereign character of non-Christian communities. From the completion of that task there logically followed the question of determining the nature of relations between such sovereign Christian and pagan states. Secondly, those activities that would violate the law of nations, and for which the communities of the New World could be in principle held responsible, are expressed in a highly conditional language. This suggests the absence of a firm conviction that such violations were sufficiently palpable (or that were even being committed) so as to warrant recourse to force in the restoration of a just order among nations. On the contrary, and thirdly, the entire corpus of De Indis is but a response not to violations on the part of the indigenous communities but to the misdeeds of Spanish power against the innocent.

In what follows, I wish to outline Vitoria's understanding of the concept of the law of nations (ius gentium), and examine its contents in terms of the rights and duties emerging from it.

\subsection{The Concept of the Ius Gentium}

The vision of the state proffered by Vitoria called for the achievement of the common good as a principal task of government and society. Similarly, the construction of this new law of nations was partially based upon Vitoria's theory of the state in terms of a teleology centered not on the particular community but on a universal community. The chief aim of collective life on a national plane becomes at once the aspiration of international society. Barthélémy, in an essay on Vitoria, thus held: "As with the state... the community of states constitutes a whole, a perfect society, an organic and living being which finds the justification for its existence in the principles derived from natural right. As with the state, this new society was ordered toward the common good of nations" 87 .

86 Carro (1947) p. 104.

87 Joseph Barthélémy, "François de Vitoria", in Les Fondateurs du Droit International (París, 1904) pp. 7-8, cited in Truyol y Serra (1947) p. 131. 
To recall, this totus orbis is not a universal monarchy, as in the vision proffered by Dante, nor is it the Stoic civitas maxima, but rather a family of nations and individuals as in the Augustinian conception. ${ }^{88}$ In Vitoria's view, there exists a natural sociability of mankind, a notion later reworked by Grotius, that is not limited by national borders; instead, it is a sociability conceived as being coextensive with the entire human species and which thus allows for the articulation of an international community. ${ }^{89}$ Again, this is but a reformulation of the Aristotelian and Thomistic idea of society as springing forth naturally and necessarily. From this natural sociability arises the ius gentium, which Vitoria, drawing upon Gaius but modifying the latter's definition, referred to as "what natural reason has established among nations is called the law of nations". ${ }^{90}$ This latter assertion expresses one aspect of the ius gentium: that the law of nations itself is represents, from a natural world-wide basis, the dictates of human reason operating in all peoples and allowing them to ascertain juridical norms or principles of justice that are universally valid and independent of human convention. ${ }^{91}$ Gaius' tract, which Vitoria quoted from only partially, illustrates this well.

The laws of every people governed by statutes and customs are partly peculiar to itself, partly common to all mankind. The rules established by a given state for its own members are peculiar to itself, and are called the jus civili; the rules constituted by natural reason for all are observed by all nations alike, and are called the jus gentium. (Institutes, I. 2. 1). ${ }^{92}$

Roman law assumed, in this manner, that moral precepts were acknowledged by all civilized societies. Phillipson has taken Vitoria's organic conception of the globe, this underlying natural sociability accompanied by the existence of a common morality and relations between discreet communities, to signify a condition of both dependence and interdependence. This necessarily implies the existence of juridical links between communities and, therefore, the existence of an international society.

The world is not, Victoria emphasizes, a fortuitous inorganic conglomeration of isolated peoples. It is, rather, an organic totality, a living entity whose constituent parts need to be harmonised by the establishment and acceptance by them of com-

\footnotetext{
88 TruYol y Serra (1993) p. 24.

89 Autho (1993) p. 24.

90 Pagden and Lawrence (1991) p. 278. In Latin the phrase reads as follows: 'Quod naturalis ratio inter omnes gentes constituit, vocatur ius gentium'. The English translation misses Vitoria's modification of Gaius's original statement, 'Quod naturalis ratio inter omnes homines constituit, vocatur jus gentium' (Justinian Institutes, I. 2. 1), whereby the word homines (men) is replaced by the term gentes (nations). The idea forged by Vitoria is that the law of nations is articulated between independent communities. This concept is repeated in Vitoria's commentaries on Aquinas's Summa Theologica, De Justitia (q.57, a. 3, 3) where we find the jus gentium referred to as positive law 'arising from the common consent of peoples and nations' ("Ita de jure gentium dicimos, quod quoddam factum est ex communi consensu omnium gentium et nationum'). For a discussion of this see Truyol Serra (1946) p. 52.

91 URDÁNOZ (1947) p. 270.

92 Wittuck (1904) p. 1.
} 
mon laws. He rejects the prevailing doctrine that a State has no superior to limit authority; its right over its territory is more absolute than that of a landlord over his field; he insists, on the contrary, on the inevitable interdependence of States, and on the limitations consequent thereon. There is a "societas naturalis gentium". This implies the notions of "state of nature" and "social contract". Originally men possessed everything in common, and so exercised equal rights over everything. Afterwards, distinct tribal communities grew up, occupying more or less varying localities. Then came the formation of national groups on more clearly defined territories. But it was never the intention of these nations to suppress all intercourse natural to men; so that "rights" incidental to the state of nature were preserved and perpetuated. ${ }^{93}$

Inasmuch as this was Vitoria's perception of the world, the ius gentium is very closely linked to natural right and is conceived as not differing entirely from it. Communities are seen as the subjects and "carriers" of international legal relations. However, as Urdánoz has observed, it is human natural reason (naturalis ratio), which dictates all norms. To the extent that such norms as are dictated by natural reason, and by the faculty and authority that express them, they are of natural right. ${ }^{94}$ This pure association with natural right ventures no further. In his commentaries on Aquinas' treatise on justice, Vitoria noted that the concept of natural right refers to that which, by its very nature, implies a relationship of equality between two things. The difference between the ius gentium and the ius naturale, however, required unveiling subtle distinctions. Drawing upon Aquinas, he first defines natural right in two ways, and, on this basis, defines the law of nations.

In a first sense, this means that something in and of itself displays a certain equality or justice, as when one returns that which has been borrowed, or by the phrase 'do unto other as you would have them do unto you', etc. In a second sense, something is adapted or suited to some other thing, with by virtue of something else. For example, that possessions are divided speaks neither of justice nor equality; rather, this act is ordered toward the achievement of peace and harmony among men, which cannot be preserved if each does not possess his goods; and it is for this reason that possession are divided.

This presupposed, my first proposition is the following: that which is suited to something, and which is absolutely just in the first sense is called natural right, that is, it is of natural right.

Second proposition: that which is suited to something and is just according to the second sense, for it is ordered toward something else that is just, is called the law of nations. Thus, that which is not equitable in and of itself, but by virtue of a rationally determined human statute, is called the law of nations. Hence, such equitableness as it possesses is not inherent but rather is due to a relationship with something

93 Phillipson (1915) pp. 180-181.

94 URDÁNOZ (1947) pp. 270-271. 
else, as for example when we speak of war and other things. It follows that the law of nations may be thus distinguished from natural right ${ }^{95}$.

Francisco Suárez (1548-1617), years later, had focused on the problem of determining the difference between the law of nations and natural right; and it was his massive treatise on law, Tractatus de legibus, that addressed this question. Like Vitoria, he had stressed the difference between natural right and the law of nations; the law of nations was an "unwritten law" emerging from human custom. "It differs from natural law," he wrote, "in that it is based on customs more than on nature; and it is distinguished from civil law by its origin, and by its universality [...] It is a law common to all nations, not established by any inclination of nature alone but by the usage of the nations" 96 . Vitoria similarly explained that the law of nations, in accordance with the teachings of Aquinas, was sanctioned by "a consensus among men" and that it should be considered as belonging more to positive law than natural law, ${ }^{97}$ a statement which Suárez reproduced when he wrote "the law of nations is simply human and positive" 98 .

What did this all mean in matters of international intercourse? Part of the answer Vitoria already gave in the passage above. Customary agreements, tacit or explicit, play a crucial role in maintaining just relationships between social agents, or between communities. But this is achieved indirectly by the very nature of customary agreements. In that same gloss on Aquinas he further illustrated matter with examples of international conduct and diplomatic practice.

[The law of nations] is the outcome of a common consensus among all peoples and nations and, in this respect, ambassadors are admitted by the law of nations, and are inviolable everywhere; in this light the law of nations approaches natural right to such a degree that natural right itself could not be observed without due regard for the law of nations. Peace is of natural right; if wars emerge, the tasks of ambassadors are necessary for the achievement of peace. In other words, if ambassadors were not admitted by the law of nations, they would not be able to bring peace... Secondly, to act against the law of nations and violate it is illicit because such an act bears an injustice committed, and a certain absence of equity. Because if the French consider our ambassadors immune, it is necessary for us to consider theirs in the same manner. So that, for example, if ambassadors are sent by one of the parties in order to reestablish peace and are not mistreated; and if the other party sends theirs and these are mistreated, it is obvious that there exists inequity and injustice ${ }^{99}$.

\footnotetext{
95 Vitoria (2001) pp. 23-24. The translation is mine.

96 Cited in García Y García (1997) p. 31.

97 Vitoria (2001) p. 26.

98 García Y García (1997) p. 29.

99 Vitoria (2001) p. 28.
} 
The role played by this law of nations is considered vital for a number of aims that are associated with justice. In this manner, the ius gentium becomes an "assistant" in the achievement and safeguarding of natural rights and equity. And it is for this very reason that Vitoria concludes, "natural right would be observed with great difficulty without the law of nations" 100 . The observation has important implications. To the extent that natural right is not formally the law of nations (since, as Vitoria observed, then it would be natural right and not the law of nations), it is also true that the law of nations, thus conceived, becomes a system of practices which nonetheless embody values, or which have as a reference point, the ethical perceptions (perceptions regarding right and wrong) of communities engaging in various forms of intercourse. In this respect, it is logical to conclude that the law of nations cannot create customs contrary to the principles of natural right. In assisting, however indirectly, in matters of justice, it becomes the manifestation of equitable principles to an extent similar to the manner in which positive human law, in Thomistic legal philosophy, expresses the principles of justice in the state. The "laws" of the law of nations seek an order of equity appropriate to the nature of man and which assist him in fulfilling his nature within the context of relations between sovereign communities.

It is important to note, moreover, that consensus is a vital aspect in the law of nations. Customary practices and associated norms are valid because consensus makes them so. In other words, custom in and of itself is an indication of consensus. Vitoria's theory of the state had already established that consensus or "majority consent" is ultimately of natural right. He thus asserted in De potestate civili, "...The will of the majority in the commonwealth is equivalent to the will of the whole commonwealth"101. Later in De Indis he similarly maintained, "In matters which concern the good of the commonwealth the decisions of the majority are binding, notwithstanding the opposition of the minority; otherwise no good action could be taken for the benefit of the commonwealth, since it is difficult to obtain unanimous agreement for any proposal". ${ }^{102}$ In his commentaries on Aquinas, he further argued, "It is of natural right that [the opinion of] the majority prevail [...]"103. In what follows, I will examine a number of the precepts of the law of nations set forth in the final part of Vitoria's De Indis.

\subsection{The Rights and Duties of Nations}

The condition of natural sociability characterizing humankind Vitoria expressed as the naturalis societatis et communicationis or "natural partnership and communication". ${ }^{104}$ It is the starting point for his examination of the just titles; and it is from this idea of natural sociability that Vitoria posited the rights and duties between communities. These included the concepts of the ius peregrinandi et intendendi or the right of immigration and residence in foreign territories; the right of free trade; the ius praedicandi or the right

\footnotetext{
100 Vitoria (2001) p. 29.

101 Pagden and LaWrence (1991) p. 31.

102 Pagden and Lawrence. (1991) p. 288.

103 This is from his commentaries on Aquinas (II-II, Q. 60, a.2), cited in Naszalyi (1948) p. 243.

104 Pagden and Lawrence (1991) p. 278.
} 
to preach religious ideas; and the principle of the freedom of the seas (which would later influence Grotius' Mare Liberum of 1609), among others. ${ }^{105}$ Apart from his discussion on rights and duties among communities, there remains one additional theme emerging from this final part of the lecture and which I will also examine here: the question of the grounds for intervention (what we would announce as humanitarian intervention) in the affairs of otherwise sovereign political communities.

Vitoria's claim that "the Spaniards have the right to travel and dwell in those countries, so long as they do no harm to the barbarians, and cannot be prevented by them from doing so," indeed appealed to that natural sociability of the human species before the creation of political structures. What natural reason, and hence the ius gentium, had established before the division of the world was free contact amongst peoples accompanied by the "humane and dutiful" trait of treating strangers with hospitality. "This right," he maintained, "was clearly not taken away by the division of property (diuisio rerum); it was never the intention of nations to prevent men's free mutual intercourse with one another by this division" ${ }^{106}$. We must understand, Vitoria continues, that those activities are lawful which are not prohibited or otherwise harmful to men. Given that the travels of the Spanish, "as we may for the moment assume", are not harmful to the barbarians they constitute licit activities. ${ }^{107} \mathrm{He}$ buttressed his case by referring to the idea that love and friendship between men (who cause no detriment) are of natural right; and that the sharing of rivers, the open sea and ports, as the ancient jurists had noted, is also of natural right. "The barbarians themselves," he added, "admit all sorts of other barbarians from elsewhere, and would therefore do wrong if they did not admit the Spaniards" ${ }^{108}$. Indeed, if the Spanish were prohibited from travelling to these territories, this would be by divine, natural or human law. It is thus the case that the Spanish could licitly engage in trade with them (on the condition they did no harm), and not be prevented from doing so either by local or Spanish princes. Man, he concluded, "is not a wolf to his fellow men"109.

Certainly this concept of free communication among peoples was fuelled by the conviction that, as in the life of the national community, intercourse among individuals was not merely natural but also necessary for the achievement of human flourishing. The Aristotelian idea of the man who lives outside of the polis as being either a god or beast, finds here its reformulation in the concept of a community of nations that engage in practices conducive to mutual benefit. This was particularly present in the assertion of trade as being, in principle, beneficial to both the Spanish and the new communities, each providing the other with those goods that either party held in abundance. Wortley notes how this

\footnotetext{
105 URdÁNOZ (1947) pp. 271-272.

106 Pagden and Lawrence (1991) p. 278.

107 Vitoria adds by way of example: "it would not be lawful for the French to prohibit Spaniards from travelling or even living in France, or vice versa, so long as it caused no sort of harm to themselves; therefore, it is not lawful for the barbarians either”. Pagden and Lawrence (1991) p. 278.

108 Pagden and Lawrence. (1991) p. 279.

109 Pagden and Lawrence (1991) pp. 279-280.
} 
was re-emphasized in Grotius' Mare Liberum and De iure belli ac pacis, which later received the appellative of the "open door" principle in colonial legislation literature. ${ }^{110}$

The discussion, in light of the concept of natural communication, now turned on the grounds for the recourse to war. Vitoria shifts to the use of conditional language. Hence, if the Spanish, by reason of marriage or birth, were prevented from taking up residence in the New World; if the aboriginals prevented the Spanish from using those resources which they had a right to dispose of; and if the Spanish were treated with violence in these matters, they had a right to use force. But this right was not without its own requisites and stipulations. The Spanish did have an obligation to "reassure [the barbarians] and convince them of their peaceful intentions"; and demonstrate "diligently both in word and deed that for their own part they have every intention of letting the barbarians carry on in peaceful and undisturbed enjoyment of their property" ${ }^{111}$. Any right of war, furthermore, had to be exercised "with moderation, in proportion to the actual offence"; and "with as little harm to the barbarians as possible since this a merely defensive war" 112 . It is clear that Vitoria was drawing not merely upon the ius ad bellum but equally the precepts of the ius in bello (outlined with greater detail in De iure belli), which placed great emphasis on the methods, or conduct of war.

A right considered crucial by Vitoria, and which Wortley perhaps anachronistically has referred to as "free speech", was that of the ius praedicandi, or the right to preach religious doctrine. Notwithstanding Vitoria's own religious inclinations, it is possible for the modern reader to ponder the conception of a right to disseminate religious ideas in terms of a more general right to communicate ideas broadly speaking. In any case, while Vitoria's justifications for maintaining this position are specifically biblical, for he cites, among others, Mark 16: 15 ("go ye into all the world and preach the gospel to every creature"), it is clear that such a propagation of religious ideas is a function of the general natural right of communication and fellowship among men. It is true that he indeed saw in the "barbarous customs" of the natives a need for instruction in ethical values, which of course were Christian. While this attitude might be considered (again, by the modern reader) as chauvinistic and paternalistic, it is also the case that, unlike many wars waged on behalf of modern political doctrines, Vitoria placed limits upon the extent to which doctrine could be preached. He initially maintained that the aboriginals were obliged to listen to the preaching of the Christian faith, and held that if there were attempts to impede preaching and prevent voluntary conversion "by killing or punishing the converts to Christ, or by deterring them by threats or other means... the Spaniards could wage war on behalf of their subjects for the oppression and wrong which they were suffering..."113 The important

110 Wortley (1938) pp. 161-162. This principle of free trade, Wortley adds, allowed the British and the Dutch to build their empires. There were apparently no prohibitions placed on colonies that prevented them from engaging in trade with other imperial powers. The same principle became part of the "'B' class of mandates under the League of Nations". Wortley (1938) p. 162.

111 Pagden and Lawrence (1991) pp. 282, 283.

112 Pagden and Lawrence (1991) pp. 282, 283.

113 Pagden and Lawrence (1991) p. 285. 
caveat was, as he had mentioned previously in his lecture, that no one could be obligated to accept the faith.

[...] if the barbarians permit the Spaniards to preach the Gospel freely and without hindrance, then whether or not they accept the faith, it will not be lawful to impose anything on them by war, or otherwise conquer their lands. This was proved above in my refutation of the fourth unjust title; and it is obvious, because no war can be just when not preceded by some wrong, as St Thomas says (ST II-II. 40. 1). ${ }^{114}$

Even within the sphere of a just title the concept of natural right is upheld; power is constrained. The right of the Spanish to preach did not annihilate other rights considered natural and inherent in man; in this instance, the freedom to rationally choose and embrace a religious doctrine.

However, the third, fourth and sixth just titles essentially refer to the protection of converts and to the resulting jurisdiction of the pope over them, now as Christian subjects. A just war could be waged against those "princes [who] try to call them back to their idolatry by force or fear"115. It was also the case that the pope might have reasonable grounds for forcefully removing infidel masters and replacing them Christian ones if most of the barbarians had been converted (properly and in the absence of terror and threats); and if there were reason to believe they could become "apostates and fall away from the faith, or else suffer persecution from these same masters because of their faith [...]"116. Similarly, by majority consent the barbarians could hypothetically elect the Spanish king as their prince, if they felt so inclined. Indeed, "In this way the Franks changed princes for the good of their commonwealth [...]"117. The underlying principle justifying these possible incursions was not merely the materialization of a new papal jurisdiction via religious conversion, and a resulting appeal to what he called "religious title" (titulus religionis). More importantly, there is the conviction that religious belief is of natural law, and thus constitutes a right that may be legitimately defended by solidarity, or what Vitoria otherwise labeled as "human amity" and "partnership". ${ }^{118}$ This idea is expressed in similar fashion when examining the idea of intervention as a function of the duty to protect the innocent against unjust death.

\subsection{InTERVENTION AND Assistance}

In an article on intervention in the thought of Vitoria, Menéndez notes that it is often the view that solidarity between states is incompatible with sovereignty. ${ }^{119}$ We are familiar with the contention that sovereign states are the highest judges (recognizing no su-

\footnotetext{
114 Pagden and Lawrence (1991) p. 285.

115 Pagden and LaWrence (1991) p. 286.

116 Pagden and LaWrence (1991) p. 287.

117 Pagden and Lawrence (1991) p. 289.

118 Pagden and Lawrence (1991) p. 286.

119 Menéndez-Reigada (1947) p. 141.
} 
perior) of their own internal comportment, and that attempts to intervene in the internal affairs of states meet with a recalcitrant, and often justifiable, defense drawing on Westphalian principles, or the principle of self-determination. Walzer thus observed:

The principle that states should never intervene in the domestic affairs of other states follows readily from the legalist paradigm and, less readily and more ambiguously, from those conceptions of life and liberty that underlie the paradigm and make it plausible. But these same conceptions seem also to require that we sometimes disregard the principle; and what might be called rules of disregard, rather than the principle itself, have been the focus or moral interest and argument. ${ }^{120}$

By what excuse may intervention be justified? Walzer's ideas, which include intervention on humanitarian grounds, are thoughtful; but he does not seem to offer a clear theoretical framework from which to work toward such a justification.

In the short, but enormously significant, fifth just title explicated in De Indis, Vitoria is explicit in stating that force may be used in circumstances in which tyrannical rule and "oppressive laws" lead the innocent to human sacrifice or "to the killing of condemned criminals for cannibalism" 121 . He added, "[...] in lawful defence of the innocent from unjust death, even without the pope's authority, the Spaniards may prohibit the barbarians from practicing any nefarious custom or rite". God had given men a commandment to care for one's neighbour; the Indians are all our neighbours and it thus incumbent upon us to defend them and even force them, by just war, if they resist, to abandon such practices. But the reasoning here was not merely based on an appeal to biblical arguments; it was implicitly an appeal to the doctrine of natural right inasmuch as it attaches to all individuals the unqualified right to life. The argument is present in De iure belli: "[...] we may not use the sword against those who have not harmed us; to kill the innocent is prohibited by natural law"122. It is the violation of a fundamental precept of natural right (the violation of justice), which, as in the just war doctrine, allows the use of force against those who unjustifiably take it upon themselves to determine when life shall cease. In this view, no authority may take away life when no injustice has been committed.

The question of intervention, and the concomitant infringement upon the doctrine of state sovereignty, goes deeper than this, however. The idea of natural rights (as in the right to life), and the impulse to protect those very rights is also predicated upon a dual conception of sovereignty: the sovereignty of the state, and the sovereignty of a universal society of mankind. In this view, sovereign states emerge of necessity, and hence by natural right (as in Vitoria's view of the state) from this wider community of which it is considered an inexorable part. This much is clear. But there is one further decisive step in this image of the world. Such sovereignty as the state rightfully possesses in the pursuit of localized or

120 WaLzer (1977) p. 86.

121 Pagden and Lawrence (1991) pp. 287-288.

122 Pagden and Lawrence (1991) p. 304. The correct translation would be "natural right" as used in the original Latin text (iure naturali). See Pereña (1981) p. 128. 
particularistic social and political life, is not perceived as being wholly independent. The organization of the world into communities of this kind, as I have pointed out earlier on, does not destroy this previous unity of mankind nor the relationship the state maintains with it. Both are perceived as existing simultaneously; and the implications of this perspective are significant. Menéndez has referred to this view in terms of the existence of "state sovereignty" and "supra-state sovereignty".

State sovereignty and supra-state sovereignty are neither contrary to one another nor antithetical since each move along different planes, each having a different formal object: state sovereignty, civil law; and supra-state sovereignty, the law of nations. One may thus maintain, in following Vitoria, that the "state has no superior"; it is truly sovereign to the extent that it remains within the limits which its own nature imposes upon it. On the other hand, there exists a superior authority or sovereignty located beyond the reach of the State, which represents the laws of Humanity that the State cannot embrace. ${ }^{123}$

As against later conceptions of absolute sovereignty, this perspective holds the view that a primary function of the state is that of upholding the rights, which pertain not merely to its citizens, but to that wider community of individuals to which both state and local citizenry belong. In this wholly organic conception of the world, once a violation of justice is committed, the ethical ordering of the state is altered because it has strayed away from the duties appropriate to its nature. And since the state is equally part of the community of mankind, the violation of justice is felt not merely within the confines of the state, but everywhere. This is similar to the Kantian view of the world, as Donaldson demonstrates: "[for Kant] the Law of Nations is concerned both with the relationship of 'one state to another,' and with 'relationships of individuals in one state to the individuals in another and of an individual to another whole state." 124 And as Kant argued in the oftquoted "Third Definitive Article" of Perpetual Peace: "The peoples of the earth have thus entered in varying degrees into a universal community, and it has developed to the point where a violation of rights in one part of the world is felt everywhere. The idea of a cosmopolitan right is therefore not fantastic and overstrained; it is a necessary complement to the unwritten code of political and international right, transforming it into a universal right of humanity" 125 . This is the tradition that perhaps inspired the Nuremberg code when referring to "crimes against humanity," and which informs Walzer's idea that humanitarian intervention, in such circumstances, is justified because it becomes a response to acts "that shock the moral conscience of mankind" ${ }^{26}$. When such matters arise, Walzer holds, one strays away from particularist arguments that defend sovereignty; and it is here that one

\footnotetext{
123 Menéndez-Reigada (1947) p. 144.

124 Donaldson (2001) p. 145.

125 KANT (1991) pp. 105-108.

126 WaLzer (1977) pp. 106-107.
} 
initiates a search for a "consensus" that will attempt to ascertain universal moral rules. ${ }^{127}$ For Vitoria, that consensus was called the ius gentium.

\section{CONCLUSION}

In this excursus, I have argued that the precepts of natural law, in the order of justice, fulfill a constitutional and critical function directed at power, whatever form it may assume. The central preoccupation underlying Vitoria's thoughts on inter-state relations is the essential dignity of the individual and of the communities of which he is an integral part. Indeed, the foundation of Vitoria's view of international relations is man, its common denominator and building block. When we discuss the ethical, the just, or simply what is "right" in politics, we are saying two things. First, that there are standards by which we judge the conduct of peoples and their governments, who are made up ultimately of individuals making choices that affect society; and that such standards are obviously not merely sources of moral criticism but also "guides" which direct politics to what is perceived as the ethically "correct". Second, we are also saying implicitly that such standards exist because we attach inherent value to individual and collective life. Logically individuals and communities must, by virtue of these standards, become the bearers of rights however we may ultimately define them. Hence, when certain decisions do not uphold those standards, as in the choices often made in the exercise of political power, the latter become in some manner detrimental to that to which we have attributed value. The gap thus produced between ethical standards and actual practice becomes a source of moral judgment. Principles become by design critical principles, which say that this or that constitutes unacceptable comportment. And so we then turn to them to uphold and defend the rights we have perceived as belonging to individuals. Vitoria's view of international relations, and of the state, substantially follows the logic of this argument.

From the perspective of Vitoria's theological view, ontologically man bears a resemblance to God, the author of natural law, to the extent that reason in him is an inheritance of the perfect divine reason of his creator. It is in that relationship and in that resemblance, that man is said to enjoy dignity and to be equal to others of his species who possess the same qualities. He is equally endowed, not merely with reason in a general sense, but with a moral sense of purpose (practical reason) that obliges him to understand the ethical ordering of the human world: those precepts of justice which are the key to peace, the common good and human flourishing in society. In the realm of political society, the sovereign power of the state ideally assists in ordering life toward these ends. But power is wielded by men who exercise choice and free will and hence is subject to abuse. It is again the appeal to the standards of natural right that places limits on what may or may not be done by those possessing state power. Natural right, which tells us what is just, fair and equitable, protects the individual and society from acts and choices that tend to destroy the order established by those precepts. Society must, in this view, uphold justice, and in the pursuit of the common good, political power must be used unselfishly toward that end.

127 WALZER (1977) p. 107. 
Vitoria's view of the operations of the international system, divided of necessity into such discrete political units bearing rights and duties on a plane of equal status, is analogous to the rights, duties, and equality characteristic of men in the sphere of national society. That organic view of a world of communities, which was predicated on the same notion of man as possessing an essential dignity, was transformed into an assertion of the essential equality and dignity of states, each the bearer of rights and corresponding duties. De Indis was an attempt to outline the principles governing state conduct, a sketch of both the permissible and of the objectionable.

The accomplished fact of imperial expansion into the New World, of the unrestricted exercise of power and its accompanying justifications Vitoria countered by turning to the natural basis of the state and international community. The first decisive step was to "construct" sovereignty beyond European civilization by first establishing that these new communities were composed of men. This assertion alone made possible all other assertions. It allowed him to establish that one was speaking of sovereign communities bearing the same rights as those of the emerging European states-system. From this it followed that by no known natural, divine, or human law (or biblical argument) could these communities be warred upon, dispossessed, or ruled over. As in his theory of the state, no one was naturally superior to anyone else, and much less lord of the world. Not even by their irreligious practices or by their sins against nature, could force be justifiably directed at them. He had thus subjected the exercise of power to critical examination on a natural right argument: namely, that by none of these justifications could the natural dominion of these communities be destroyed. None of their cultural practices meant they had lost their natural dominion, nor did they represent an injustice committed against the emperor or pope.

His final statements outlined provisionally, and conditionally, those violations, which could possibly justify war and Spanish rule. At bottom, Vitoria was not creating justifications for imperial expansion. Rather, he was building a view of the world based on a perceived natural sociability of mankind, the same sociability that gave rise to national society. From this condition it followed that there emerged rights and duties, the ius gentium, which defined the just ordering of inter-state relationships. The idea of natural partnership and communication was raised to the rank of a right from which arose similar rights and duties between communities. The achievement of the common good and justice in the world theatre required various interactions and contacts such as the simple communication of ideas between men, and trade, so long as such interactions did not cause harm. The existence of a world divided into discrete communities did not, of course, destroy that sociability and thus imposed an obligation to respect those rights everywhere. A transgression of those rights could possibly result in justifiable grounds for war; hence, murder or crimes against humanity were, for Vitoria, a heinous violation of justice. The taking of innocent life was not only a transgression of the natural rights of men, but equally an attack upon the moral conscience of mankind providing a reason for intervention. In this respect, Vitoria's notion of sovereignty is not absolute but porous, because the sovereignty of the state, a 
comparatively impermanent form of organization, ${ }^{128}$ is limited by its obligation to protect and further human life and flourishing.

International society is, then, a society of states and of individuals. These two spheres are inextricably linked and brought into a form of unity by the overarching framework of justice. Justice, which brings into view the notions of equity, equality, fairness, and alterity, are what lead states and inter-state relations to the achievement of peace and of the common good, so that man may develop his potentialities and those aims that are part of his nature in the absence of arbitrary violence directed against him. In this manner, the idea of iustitia or of the just, is seen by Vitoria as defining the rights and duties of men both within states and between them. His works stand as a part of a tradition ${ }^{129}$ of the European Renaissance that contributed to the development not only of political and legal thought but also to an established religious perspective on international ethics.

\section{BIBLIOGRAPHY}

Aristotle (1946): The Politics of Aristotle. (Translated by Ernest Barker, Oxford, The Clarendon Press).

Aristotle (1980): The Nichomachean Ethics. (Translated by David Ross World's Classics Paperback. Oxford, Oxford University Press. Reprint, 1925).

Belda Plans, Juan (2000): La Escuela de Salamanca y la Renovación de la Teología en el Siglo XVI (Madrid, Biblioteca de Autores Cristianos).

Brown, Chris (2002): Sovereignty, Rights and Justice: International Political Theory Today (Cambridge, Polity Press).

Carro, Venancio (1947): "Los Fundamentos Teológicos-jurídicos de las Doctrinas de Vitoria”. Ciencia Tomista, no. 223: 95-122.

Coleman, Janet (2000): A History of Political Thought: From the Middle Ages to the Renaissance (Oxford, Blackwell Publishing).

Donaldson, Thomas (2001): "Kant's Global Rationalism”. In: Terry Nardin and D.R. Maple (edit.), Traditions of International Ethics, 136-157 (Cambridge, Cambridge University Press. Reprint, 1992).

Folgado, Avelino (1959): "Los Tratados De Legibus y De Iustitia et Iure en los Autores Epañoles del Siglo XVI y Primera Mitad del XVII”. La Ciudad de Dios CLXXII, no. 3: 275-302.

García y García, Antonio (1997): “The Spanish School of the Sixteenth and Seventeenth Centuries: a Precursor of the Theory of Human Rights". Ratio Iuris 10, no. 1: 25-35.

Gierke, Otto (1968): Political Theories of the Middle Age (Translated by Frederic William Maitland. Cambridge, Cambridge University Press. Reprint, 1900).

128 Martin Wight similarly noted that the states-system, from the perspective of history, is a contingent phenomenon, a unique form of political organisation that we tend to view as normal, when it is actually exceptional to the extent that empire has historically been the dominant paradigm. He thus argued that while states are the rightful members of international society, its members are ultimately individual men. WIGHT (1977) Systems of States, ed. Hedley Bull (Leicester: Leicester University Press).

129 Folgado (1959) pp. 275-302. 
Valenzuela-Vermehren, Luis — "Empire, Sovereignty, and Justice in Francisco de Vitoria’s International Thought:...”

GonzÁlez, Jaime (1984): “La Junta de Valladolid Convocada por el Emperador”. In: et al Demetrio Ramos, (edit.), La Etica en la conquista de America: Francisco de Vitoria y la Escuela de Salamanca (Madrid, Consejo Superior de Investigaciones Científicas) 199227.

Grotius, Hugo (2001): On the Law of War and Peace (Translated by A.C. Campbell. Kitchener, Batoche Books).

Hamilton, Bernice (1963): Political Thought in Sixteenth-Century Spain: A Study of the political ideas of Vitoria, De Soto, Suárez, and Molina. (Oxford, Clarendon Press).

Kant, Immanuel (1991): Political Writings (edit.) Hans Reiss. (Cambridge, Cambridge University Press).

Mattingly, Garrett (1963): Renaissance Diplomacy The Bedford Historical Series (London, Jonathan Cape. Reprint, 1955).

Menéndez-Reigada, Ignacio G. (1947): "El Derecho de Intervención según Vitoria”. Ciencia Tomista, no. 223: 139-150.

Munro, Dana Carleton (1931): “The Western Attitude Toward Islam during the Crusades". Speculum 6, no. 3: 329-343.

Naszalyi, Emilio (1948): El Estado según Francisco de Vitoria (Madrid, Ediciones Cultura Hispánica).

Noreña, Carlos G. (1975): Studies in Spanish Renaissance Thought (The Hague, Nijhoff).

Nys, Ernest (1917): "Francisci de Victoria: De Indis et De iure belli relectiones", The classics of international law, Vol. 7 (Washington, Carnegie Institution of Washington).

Pagden, A. R., And Lawrence, Jeremy (1991): Francisco de Vitoria. Political Writings, Cambridge texts in the history of political thought. (Cambridge, Cambridge University Press).

PARry, John H., and KEITH, Robert G. (1984): New Iberian World: A Documentary History of the Discovery and Settlement of Latin America to the Early 17th Century. Vol. 1. (New York, Times Books).

Pereña, Luciano (1967): Francisco de Vitoria. Relectio de Indis o Libertad de los Indios, Corpus Hispanorum de Pace (Madrid, Consejo Suprerior de Investigaciones Científicas).

Pereña, Luciano (1981): Francisco de Vitoria. Relectio de Iure Belli o Paz Dinámica: Escuela Española de la Paz, Primera Generación 1526-1560. Vol. VI, Corpus Hispanorum de Pace. Madrid, Consejo Suprerior de Investigaciones Científicas.

Phillipson, Coleman (1915): "Franciscus a Victoria (1480-1546). International Law and War "Journal of the Society of Comparative Legislation 15, no. 2: 175-197.

Recaséns Siches, Luis (1931): Las Teorías Politicas de Francisco de Vitoria: Con un Estudio sobre el Desarrollo de la Idea del Contrato Social (Madrid, Sucesores de Rivadeneyra, S.A).

Sánchez Agesta, Luis (1959): El Concepto del Estado en el Pensamiento Español del Siglo XVI. Madrid, Instituto de Estudios Políticos.

ScotT, S.P. (edit.) (1932): The Civil Law: Including The Twelve Tables, The Institutes of Gaius, The Rules of Ulpian, The Opinions of Paulus, The Enactments of Justianian and The Constitutions of Leo. Vol. II. Cincinatti, The Central Trust Company. 
Sepúlveda, Juan Ginés de (c.1544): "Democrates Alter: Or, on the Just Causes for War against the Indians" http://www.columbia.edu/acis/ets/CCREAD/sepulved.htm (accessed 3 April Access).

Truyol Serra, Antonio (1946): Los Principios del Derecho Público en Francisco de Vitoria. (Madrid, Ediciones Cultura Hispánica).

Truyol y Serra, Antonio (1947): “Doctrina Vitoriana del Orden Internacional”. Ciencia Tomista, no. 223: pp. 123-138.

Truyol y Serra, Antonio (1993): “El Derecho de Gentes como Orden Universal”. In La Escuela de Salamanca y el Derecho Internacional en América: del Pasado al Futuro, (edit.) Araceli Mangas Martín, 17-25. Salamanca, Asociación Española de Profesores de Derecho Internacional y Relaciones Internacionales.

Tuck, Richard (1999): The Rights of War and Peace: Political Thought and International Order from Grotius to Kant (Oxford, Oxford University Press).

Urdánoz, Teófilo (1947): "Vitoria y el Concepto de Derecho Natural.» La Ciencia Tomista, no. 234: 229-288.

Urdánoz, Teófilo (1967): "Síntesis Teológico-Jurídica de la Doctrina de Vitoria". In Francisco de Vitoria. Relectio de Indis o Libertad de los Indios, (edit.) Luciano Pereña, XLIIICXLII. Madrid, Consejo Suprerior de Investigaciones Científicas.

Vitoria, Francisco de (1998): Sobre el Poder Civil, Sobre los Indios, Sobre el Derecho de la Guerra. Translated by Luis Frayle Delgado Clásicos de Pensamiento 137, (edit.) Antonio Truyol y Serra. Madrid, Editorial Tecnos, S.A.

Vitoria, Francisco de (2001): La Justicia. Translated by Luis Frayle Delgado Clásicos de Pensamiento 147, (edit.) Antonio Truyol y Serra. Madrid, Editorial Tecnos, S.A.

Walzer, Michael (1977): Just and Unjust Wars. 3rd ed. NewYork, Basic Books.

White, Kevin (edit.) (1997): Hispanic Philosophy in the Age of Discovery. (edit.) Jude P. Dougherty, Studies in Philosophy and the History of Philosophy. Washington, D.C., The Catholic University Press of America.

Wight, Martin (1977): Systems of States, (edit.) Hedley Bull. Leicester, Leicester University Press.

Wight, Martin (1992): International Theory: the Three Traditions, (edit.) Gabriele Wight and Brian Porter. London, Holmes \& Meyer for The Royal Institute of International Affairs.

Wittuck, E.A. (edit.) (1904): Gaius: Institutes of Roman Law. (Oxford, Clarendon).

Wortley (1938): "Idealism in International Law: A Spanish View of the Colonial Problem". The Grotius Society, no. 24. 